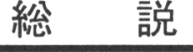

\author{
脂質の生命科学 \\ 細胞の分化と糖脂質の役割 \\ 斎 藤 政 樹 \\ 自治医科大学血液医学研究部門造血発生 \\ (开329-04 栃木県河内郡南河内町薬師寺)
}

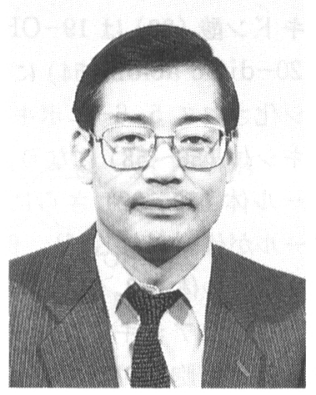

\title{
Biological Functions of Sialoglycosphingolipids (Gangliosides) as Differentiation-Inducers as well as Differentiation- Markers in Human Hematopoietic Cells
}

\author{
Masaki SAITO \\ Division of Hemopoiesis, Institute of Hematology, Jichi Medical School \\ (3311-1 Yakushiji, Minami-kawachi-machi, Kawachi-gun, Tochigi-ken, ₹329-04)
}

Glycosphingolipids(GSLs), which are amphipathic molecules composed of both hydrophobic and hydrophilic moieties and synthesized by a group of Golgi enzymes, glycosyltransferases, are located almost exclusively on the outer leaflet of plasma membranes of mammalian cells in general, and have become known to show unexpectedly vast molecular heterogeneity due to the recent uncovering of extremely minor constituents by means of remarkable development of analytical methods, which include the immunochemical analyses using monoclonal antibodies highlyprogressed in recent years. Furthermore, GSLs have been considered to be involved in cellular interactions and cell growth regulations, changing characteristically their composition and biosynthesis during cell development, differentiation, and oncogenic transformation although they constitute only a small portion of the cell surface glycoconjugates. In addition, acidic GSLs, gangliosides, have been recently shown to exhibit special receptor-functions for exogenous, bioactive factors such as bacterial toxins, hormones, and interferons. GSLs are classified into three major molecular series, i.e. globo-, lacto-, and ganglio-type, according to their carbohydrate structures, and various cells and tissues have characteristic compositions and structural specificities as to their GSLs. We and other investigators have recently found that human and murine hematopoietic malignant cells show ganglioside profiles characteristic of their cell lineages and differentiation-stages, serving as complemental differentiation-markers for both normal and malignant hematopoietic cells, and further, discovered that particular ganglioside molecules themselves, which specifically increase during differentintion along particular cell lineages induced by a variety of chemical agents, exhibit remarkably potent differentiationinducing and growth-inhibitory activities on human myelogsnous leukemia cells. On the basis of these recent findings, some important biological functions of CSLs, especially sialoglycolipids, will be discussed in special reference to cell differentiation.

\section{はじめに}

元来, 細胞膜を構成する微量成分として, その分子構 造の研究が中心であった糖脂質は，近年の分析手段の目
賞ましい発達にるる超微量成分の発見・構造決定之相 まって, その生物学的機能という動的側面の研究が脚光 を浴び, 従来の研究の流机にインパクトを与えつつ, 大 きな研究転換の時期に差し掛かっているように見える。 
糖脂質は親水基と疎水基からなる両親媒性分子で，複 合糖質に分類される一分子群である。糖残基の貯蔵形態 としての側面も持ち, 遗伝子で直接コードされる一連の 特異的糖転移酵素によって生成される。分子群内に見ら れる糖鎖の多様性が特に注目され, 表面膜の受容体機能, 細胞間相互認識への介在, 特異的抗原構造の形成之言っ た細胞社会学的生理機能を拉っていると考えられるが, その実体解明は今後の緊急課題となっている。本稿では シアロスフィンゴ糖脂質, ガングリオシド, 特定分子種 のヒト骨髄性白血病細胞の分化誘導・増殖抑制作用を中 心に細胞分化之脱分化，及びこれらに関連した糖脂質研 究の現況を概説し，糖脂質の動的な生物・医学的意義の 一端を考察したい。

\section{1 血球分化}

かりゅう (顆粒) 球, 単球, 赤血球, 血小板, リンパ 球など各系統の血球は一定の寿命を有し，かつ数的, 質 的に恒常性が保たれている。それは造血組織で常に活発 な各種血球の産生（増殖と分化）が行われ恒常的供給が 維持されているからである。このためには各種血球への 分化能を持ち, 自己複製可能な「造血幹細胞」の存在が 理論的に必要で，既に 1920 年代からその存在が主張さ れていた。この幹細胞の増殖・分化と基本的にかかわる 種々の液性因子が知られ, 最近その大部分が遺伝子ク ローニングされている(図-1)。造血幹細胞は「未分化 単核細胞で成熟を伴わない自己複製が可能，かつ特定条
件下で各種血球へ分化・成熟できる細胞 ${ }^{\prime)} 」 と$ 定義され るが，現在でもなお単一の単核細胞を取り出して，それ を造血幹細胞であると断定することは不可能に近い。幹 細胞の自己複製か分化かの決定機序には幾つかの仮説が ある。造血微小環境で分化が誘導される Deterministic model ${ }^{2)}$, 分化がある一定の序列で進行するカスケード ・モデル ${ }^{3)}$, 自己複製か分化かの決定は推計学的確率の みによるとする Stochastic model ${ }^{1)}$ (図一2) 等が提唱 されている。造血幹細胞・単細胞培養法の最近の進歩に よって, 多能性幹細胞が段階的, 推計学的に分化能の多 様性を減弱させ, 最終的に単一系統の成熟血球へ分化す ること, 従ってこの過程で分化能の多様性において様々 な段階の前駆細胞が存在することが in vitro で実証 ${ }^{1)}$ されるようになり, Stochastic model 説が信頼性を獲 得しつつある。しかしながらこの正常血球の分化過程で の物質的变化, 例えば糖脂質変化なよ゙, を生化学的レベ ルで検索同定することは，方法論的な制約から現状では 至難の業である。従って, 様々な血球系の細胞株を樹立 して分化を誘導し，その過程でできるだけ均一な細胞集 団を充分量採集して生化学的分析を行い, 正常血球分化 における変化を推定する事が多い。糖脂質研究の現状も 同様である。

\section{2 糖脂質の化学構造, その構築之機能}

動物細胞の代表的糖脂質, スフィンゴ糖脂質, の基本 構造は長鎖塩基スフィンゴシンに脂肪酸が酸アミド結合

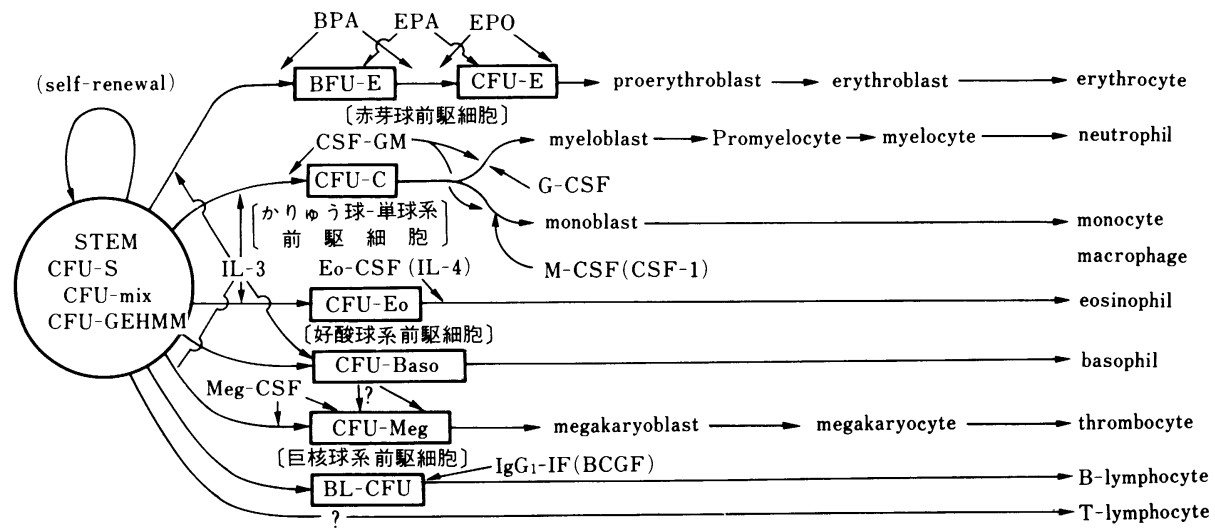

CFU-S, colony-forming unit inspleen U(脾)コロニー形成細胞 CFU-mix, mixed colony-forming unit混合コロニー形成細胞 $B F U-E$, burst-forming unit erythroid赤芽球コロニー群形成細胞 CFU-E, colony-forming unit erythroid赤芽球コロニー形成細胞 CFU-C, colony-forming unit in culture培䓹コロニー形成細胞 (CFU-GM, colony-forming unit granulocyte/macrophage) かりゅう球マクロファーシコロニー形成細胞

CFU-Eo, eosinophil colony-forming unit好酸球コロニー形成細胞 CFU-Baso, basophil colony-forming unit好塩基球コロニー形成細胞 CFU-Meg, colony-forming unit megakaryocyte巨核球コロニー形成細胞 BL-CFU, B lymphocyte colony-forming unit Bリンパ球コロニー形成細胞 BPA, burst promoting activity パースト促進因子
EPO, erythropoietin

$\operatorname{CSF}(\mathrm{CSA})$, colony stimulating factor (activity)

( GM-CSF, granulocyte-macrophage-colony-stimulating factor G-GSF, granulocyte- colony-s timulating factor M-CSF, macrophage-colony- stimulating factor Eo-CSF, eosinophil colony stimulating factor好酸球コロニー刺激因子 $\mathrm{Tp}$, thrombopoietin

EPA, erythroid potentiating activity

IL-2, interleukin-2 IL-3, interleukin-3

IL-4, interleukin-4 (Eo-CSF, BCGF)

$\mathrm{IgG}_{1}-\mathrm{IF}, \mathrm{IgG}_{1}$ induction factor (BCGF)

IL-5, interleukin- 5 IL-6, interleukin- 6 トロンポポエチン

図-1 血球の系統分化・成熟と造血因子 


$\begin{array}{lllll}\text { Toti-potential } & \text { Pluripotent } & \text { Oligopotent } & \text { Unipotent } & \text { Terminally } \\ \text { Stem Cells } & \text { Progenitors } & \text { Intermediate } & \text { Progenitors } & \text { differentiated } \\ \text { (Self-renewal) } & & \text { Progenitors } & & \text { mature cells }\end{array}$

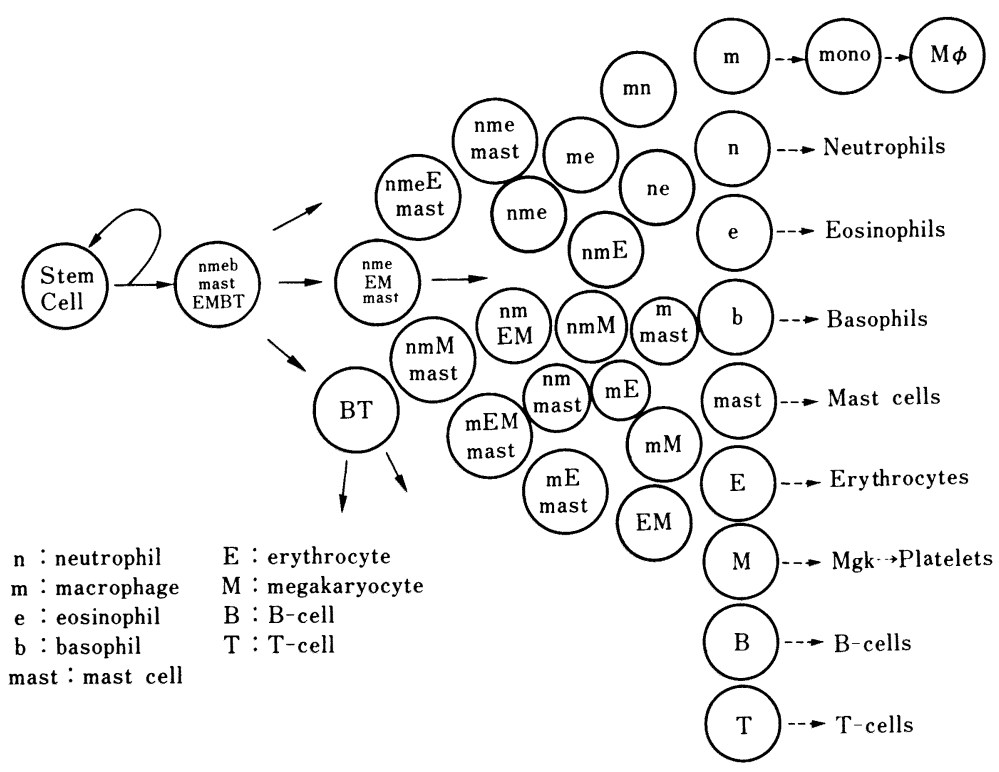

図-2 造血系細胞分化の Stochastic model ${ }^{1)}$

したセラミド基が様々な糖鎖と縮合したグリコシドであ る(図-3 A)。スフィンゴシン塩基, 脂肪酸, 糖鎖構造 の種類により多様な分子種群が形成され, スフィンゴシ ン塩基として 4ースフィンゲニンが最も多く見いだされ る。構成脂肪酸は炭素数 16 24 が主体で, 起源により 炭素数 20 以上の長鎖酸が多いもの，ヒドロキシル基を 持つ $\alpha$ 一ヒドロキシ酸が多い分子種等が見いだされる。

糖脂質の溶解性等の物理・化学的性質は糖鎖長が伸長し 糖鎖構造が複雑化するに従い，セラミド基よりむしろ糖 鎖構造に依存する。従って, 糖脂質分類は糖鎖構造や糖 鎖長（糖残基数）に基づくことが一般的で（図-3 B), 糖残基の置換基の種類により中性糖脂質, 硫脂質 (硫酸 基を含む糖脂質)，ガングリオシド（シアル酸を含む糖 脂質）と 3 大別される。フコースを含む糖脂質をフコリ ピドと別称することも多い。特に最近は糖残基数 20〜 50 の極めて長い糖鎖を持つ糖脂質が分離され注目され ている ${ }^{4)}$ 。糖鎖の基本的骨組み構造（構成単糖の種類, 配列順序, 結合炭素位, アノマー構造等) に基づいてグロ ボ系，ラクト系，ムコ系，ガングリオ系，ガラ系に分類 され, 各分子種系には特徴ある 3 糖構造が共通基本構造 として含まれる(図-3 B)。更に次のような糖鎖構造上 の特徴が列挙される:(1)グロボ系は一般にフコース, Gal, シアル酸などの糖残基付加は認めら机ない；(2) ラクト系は多様な糖残基, シアル酸, フコース, $\alpha-1 \beta-$ ガラクトースの付加が観察され, 同時に $N$-アセチルラ
クトサミン $(\mathrm{Gal} \beta 1 \rightarrow 3,4 \mathrm{GlcNAc} \beta 1 \rightarrow 3,6)$ を基本之 する直鎖又は分岐鎖の「繰り返し構造」が存在し最も多 彩な分子種群を形成している。シアル酸残基を含むラク 卜系分子種は、アミノ糖を含まない短糖鎖ガングリオシ ド $\mathrm{GM}_{3}$ と共に, 非神経系組織の主要ガングリオシドと なっており，フコースを含むラクト系分子種は主要な血 液型物質である；(3) ガングリオ系糖脂質は一般にシア ル酸残基を含む（シアリル化）。シアリル化されていな い分子種もまれに存在し，特異的な表面抗原を形成して いる。フコース残基を含むガングリオ系分子種も少数な がら見いだされている。

糖脂質は主に表面膜脂質二重層外側分子層に非対称性 に局在する普遍的な膜微量構成分であり, 多種多様な動 物細胞から分離された表面膜にあまねく存在し，その量 は内膜系に比へ遙かに多い。しかし中枢神経系を別にす れば細胞総脂質の数パーセントを超えることはなく, リ ン脂質に比べ遙かに微量な膜構成分である。疎水基セラ ミドを脂質二重層に埋め込み親水基糖鎖を細胞外側に配 向した非対称性局在様式は表面膜に構造上の剛性 Rigidity を与え, 細胞形態を維持する上でも合目的的で ある4)。セラミドは安定な水素結合を形成するための水 素受容基 (amide carbonyl 基) と水素供与基 (hydro$\mathrm{xyl}$ 基) とを合わせ持ち, 水素受容基 (ester carbonyl 基）のみを有するグリセリド glycerides（代表的なリ ン脂質の疎水基）に比べ，より構造上の女定性を賦与す 
(A)

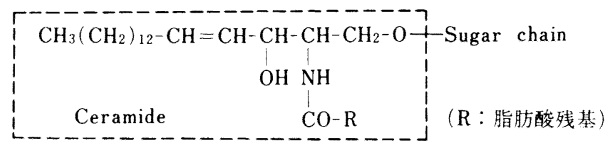

( $\mathrm{R}$ : 脂肪酸残基)
(A) Glc
(C) GlcNAc
(B) Gal
(D) GalNAc

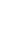

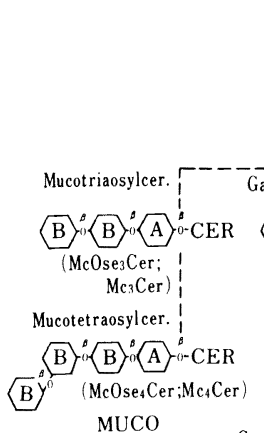
Gangliotetraosylcer. $\mathrm{B} \mathrm{B}_{1}^{03}$
GANGLIO
D) 1 B $\circ: \mathrm{A} ; \mathrm{CER}$ $\mathrm{Gg}_{3} \mathrm{Cer}$

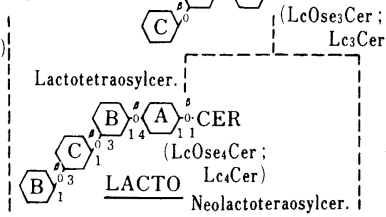
B $0^{\circ} \mathrm{A} \overbrace{(\mathrm{LcCer})}^{\mathrm{CER}}$

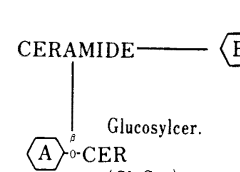
Galactosylcer. Galabiosylcer.
GALA
(GalCer) B ${ }^{\circ} \mathrm{B}-\mathrm{CER}(\mathrm{GaOse} 2 \mathrm{Cer} ; \mathrm{Ga} 2 \mathrm{Cer})$

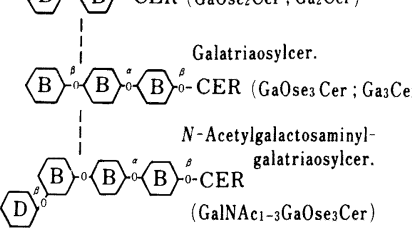

分類は IUPAC-IUB の命名委員会の提唱 [IUPAC-IUB Commission on Biochemical Nomenclature : Lipids (1977) 12, 455]に基づいている。この命名法では糖鎖部分を Ose で表し, globo 系 4 糖鎖を Globotetraose (GbOse ${ }_{4}$ と略記) と呼び，これにセラミド (Cer と略記) が結合した糖脂質 Globotetraosylceramide は図中に記

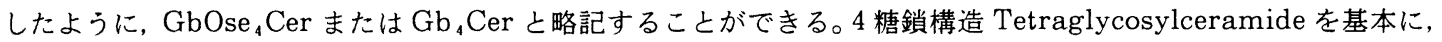
これより糖鎖の短い糖脂質は Globotriaosylceramide (GbOse ${ }_{3}$ Cer または $\mathrm{Gb}_{3}$ Cer と記す。別名 Ceramide triglycoside), Gangliotriaosylceramide ( $\mathrm{GgOse}{ }_{3} \mathrm{Cer}$ または $\mathrm{Gg}_{3} \mathrm{Cer}$ と記す。別名 Asialoganglioside $\mathrm{GM}_{2}$ )なよ゙ と呼ばれる。一方, 4 糖鎖構造より長い糖鎖を持つ糖脂質は, この誘導体と見なし, 付加される糖残基がセラミド側 から何番目 (ローマ数字で表記) の糖残基の何番目（アラビア数字でローマ数字の右肩に表記）の炭素位に，よ゙のよ うにアノマー結合しているかを次のように表記する。例えば, Forssman 抗原 (GalNAc $\alpha 1 \rightarrow 3$ GalNAc $\beta 1 \rightarrow 3$ Gal $\alpha 1 \rightarrow 4$ Gal $\beta 1 \rightarrow 4$ Glc $\beta 1 \rightarrow 1$ Cer) は IV ${ }^{3} \alpha$ GalNAc-Gb Cer または Gb ${ }_{4}$ Cer と略記される。またGanglioside $\mathrm{GM}_{1}$ は II ${ }^{3} \alpha \mathrm{NeuAc}-\mathrm{Gg}_{4} \mathrm{Cer}$, Fucolipid の $\mathrm{Le}^{5}$ 抗原は III ${ }^{4} \alpha \mathrm{Fuc}-\mathrm{Lc}_{4} \mathrm{Cer}$ と略記される。ガングリオシ ドについては, 従来からの慣用名 Ganglioside $\mathrm{GM}_{3}, \mathrm{GM}_{2}, \mathrm{GM}_{1}$ 等が使われる場合が依然として多い。

\section{図-3 スフィンゴ糖脂質の基本構造と糖鎖構造に基づく分子種群の分類}

ることができる4)。糖鎖の細胞外側への配向はこの構造 を介して外界の刺激が細胞内へ伝達され, 様々な生物反 応が引き起こされることを意味している。細胞の抗原性, 免疫原性等, いわば「細胞の顔」を決定し特徵づけてい るのがこの糖鎖構造であり, 細胞間認識機構やその他細 胞社会学的に重要な諸機能を担っていると考えられるゆ えんである。

\section{3 細胞增殖制御と分化に関与する糖脂質}

レクチンでリンパ球を刺激すると糖脂質特定分子種の 生合成が増大, 糖脂質パターン（糖脂質分子の種類と各 含量の総称）が特異的に変化し, T,B 両リンパ球の相互 識別が可能となる ${ }^{51}$ 。正常線維芽細胞株では細胞が増殖,
細胞同士が接触すると「接触阻害」が起こるが, その直 前にある種の糖脂質生合成が増大する ${ }^{6)}$ 。これは糖脂質 の生合成や局在が細胞周期に密接に関連していることを 示唆する。しゅよう (腫瘍) 細胞では細胞接触による糖 脂質生合成増大「Glycolipid contact response」は生 じないが，この性質が直ちに造しゅよう性と直結するも のではない6)。

短鎖脂肪酸, 特に酪酸はしゅよう細胞の飽和濃度を下 げ, 接触阻害を回復させる分化誘導因子として作用し, この時ガングリオシド $\mathrm{GM}_{3}$ 合成酵素の活性化と $\mathrm{GM}_{3}$ 合成量の著増が生ずる ${ }^{7)}$ 。発がん プロモーター TPA (12-O-tetradecanoyl phorbol-13-acetate) もヒト 黒色しゅ細胞の分化誘導因子として作用し, メラニン合 
成と共にガングリオシド $\mathrm{GM}_{3}$ 合成を増大させる ${ }^{8)}$ 。脂 溶性ビタミン $\mathrm{A}$ 誘導体レチノイドも強力な分化誘導剤 で, しゅよう細胞の增殖動態と接触阻害を正常に回復さ せ, 同時にガングリオシド合成に関する Glycolipid contact response を回復させる ${ }^{9)}$ 。

\section{4 悪性転換（がん化）と糖脂質}

発がんウイルスや化学発がん剂で悪性転換した多種類 の細胞とヒトがんなど自然発生のがん細胞に共通して観 察される糖脂質変化がある。この変化は悪性転換に関連 した最も共通性の高い形質発現の一つ之考えられ, 基本 的には 2 種類に分類される：(1) より複雑な糖鎖をもつ 糖脂質合成が阻止され，その前駆体が蓄積する变化，(2) 悪性転換前にはなかった新しい糖脂質合成が誘導される 変化, である。又, 「発がん原因物質之標的細胞の種類 の組み合わせ」に依存する様々な糖脂質組成・代謝変化 が観察される。第 (2) の変化で生ずる新しい糖脂質は一 括して「がん関連抗原」と総称され，フォルスマン抗原 陰性組織由来のしゅように発現するフォルスマン糖脂質 合成, O又はB 血液型のヒトのしゅようにおけるA型抗 原出現, $\mathrm{p}$ 血液型のヒトのしゅようにおける $\mathrm{P}_{1}$ 抗原出 現, ヒトがんにおけるフコシルセラミド出現, ラット肝 がんにおける種々のフコリピドの出現等が知られてい る ${ }^{6)} 。 N-2$-fluorenylacetamide による肝が ん発生 初期過程でジシアロガングリオシド合成経路 $\left(\mathrm{GM}_{3} \rightarrow \mathrm{G}\right.$ $\left.\mathrm{D}_{3} \rightarrow \mathrm{GD}_{1 \mathrm{~b}} \rightarrow \mathrm{GT}\right)$ が高度に障害されモノシアロガング リオシド合成経路 $\left(\mathrm{GM}_{3} \rightarrow \mathrm{GM}_{1} \rightarrow \mathrm{GD}_{1 \mathrm{a}}\right)$ が活性化 ${ }^{10)}$ される結果, $\mathrm{GD}_{3}, \mathrm{GD}_{1 \mathrm{~b}}, \mathrm{GT}$ が激減し, $\mathrm{GM}_{1}, \mathrm{GD}_{1 \mathrm{a}}$ が蓄積する変化は第 $(1)$ の糖脂質変化に属する ${ }^{6)}$ 。

造しゅよう性の高いL細胞要株では造しゅよう性の低 い親株に比べ長糖鎖中性糖脂質, ガングリオシド $\mathrm{GM}_{3}$ が減少/欠損し, これらの糖脂質レベルが悪性度を反映 すると言われる ${ }^{6)}$ 。悪性度の高い自由細胞型ラット腹水 肝がんでは悪性度の低い島形成型に比べ，グロボシド, ガングリオシド $\mathrm{GM}_{3}$ 及びこれらの合成酵素が欠損して いる ${ }^{11)}$ 。Kirsten 肉しゅウイルスで悪性転換したマウ ス $3 \mathrm{~T} 3$ 細胞の悪性度（転移性）はガングリオ系中性糖 脂質アミノ CTH の含有量と膜表面に「露出されている か隠ぺい(蔽)されているか」に密接に関連している ${ }^{12)} 。$

\section{5 外来性糖脂質及び抗糖脂質抗体の生理活性}

培養系に添加された糖脂質は de novo 合成された 分子のように細胞膜に局在, 機能を発揮する。例えば $\mathrm{Le}^{\mathrm{a}-}$ 赤血球を $\mathrm{Le}^{\mathrm{a}}$ 糖脂質とインキュベートする之, $\mathrm{Le}^{\mathrm{a}+}$ 赤血球に変換する。糖タンパク抗原物質はこのよ

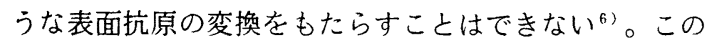
ような外来性に糖脂質を細胞に与える方法は細胞の増殖 ・分化に関連したその生理的, 病理的機能を探る上で重
要であり, 完全無血清培養法を適用すると,この機能は, より顕著にしかも各分子に特異的な活性として認められ る。外来性ガングリオシド分子の多くはセラミド基を表 面膜脂質二重層に埋め込んだ安定した分子配向をとると 考えられるが, de novo 合成された分子に比ベシアリ ダーゼで水解されやすく ${ }^{13)}$ ， トリプシン処理で除去さ れることもある ${ }^{6)}$ 。八ムスターNIL 細胞をグロボシド とインキュベートすると細胞膜中のこの糖脂質レベルが 2 倍以上になり, その結果細胞の基質接着性は增大し, 悪性転換細胞 NIL p るようになり，細胞周期上 $\mathrm{G}_{1}$ 期が 2 倍に延長する ${ }^{6)}$ 。 ガングリオシド $\mathrm{GM}_{1}, \mathrm{GD}_{1 \mathrm{~b}}, \mathrm{GT}_{1 \mathrm{~b}}$ 等を $3 \mathrm{~T} 3$ 細胞及 び悪性転換変異株 $3 \mathrm{~T} 3_{\mathrm{SV} 40}$ の培養系に加えると両細胞 の增殖速度と飽和濃度が共に抑制される ${ }^{13)}$ 。又, NIL 細胞の無血清培養系で線維芽細胞増殖因子リセプターの 機能を制御するガングリオシド分子は $\mathrm{GM}_{1}$ ではなく $\mathrm{GM}_{3}$ であること ${ }^{14)}$ が解明され, 特定の生理活性を有 する糖脂質分子種の同定も可能となった。この研究方法 は最近の「ガングリオシドによるヒト白血病細胞分化誘 導」発見 ${ }^{15)}$ １6) の基本ともなり，またフィブロネクチ ン等グリコカリックス層の物質にも適用されて増殖, 運 動, 形態等がこれらによっても修飾されることが明らか になった ${ }^{6)}$ 。

糖脂質機能を外来性に探るもう一つの方法は特異抗体 を培養系に加えて, 細胞機能・形態变化を追究すること である ${ }^{6)}$ 。NIL 細胞と BALB/C 線維芽細胞の増殖期 に抗 $\mathrm{GM}_{3}$ 抗体を添加すると増殖が著明に抑制され， $\mathrm{GM}_{3}$ 合成が 1.5 倍に増大する。細胞濃度の飽和状態あ るいは悪性転換細胞に対して抗 $\mathrm{GM}_{3}$ 抗体の作用は認め られないので, この作用は接触阻害誘導に類似した反応 である6)。抗 $\mathrm{GM}_{3}$, 抗 $\mathrm{GM}_{1}$ 抗体によって Astrocytoma 細胞の増殖抑制, アデニルシクラーゼ活性上昇, グアニルシクラーゼ活性低下が観察される ${ }^{6)}$ 。 BALB/ $\mathrm{C}$ 線維芽細胞を抗 $\mathrm{GM}_{1}$ 抗体で処理すると発がんウイル スによる悪性転換が阻止され，ラットじん臟 NRK 細 胞をあらかじめ抗 $\mathrm{GM}_{3}$ 抗体と反応させておくと, トリ 肉しゅ(腫)ウイルス LA 23, LA 25 によるがん化が完 全に阻止される ${ }^{6)}$ 。

\section{6 血球分化と糖脂質}

血球の糖脂質研究は既に 25 年以上の歷史をもち, 特 にヒト赤血球に関しては数十種に及ぶ分子種が分離・同 定されている。白血球についても血球分離装置での大量 細胞採取法の採用で急速な研究進展が見られ, 既に 20 種 以上の分子構造が明らかにされた。糖脂質パターンは一 般に細胞の種類, 組織・臟器別, 動物種あるいは亜種, 株ごとに特徵があり，発生・分化の段階でも異なる 「Fingerprint」である。ヒト血球についても, 赤血球, 


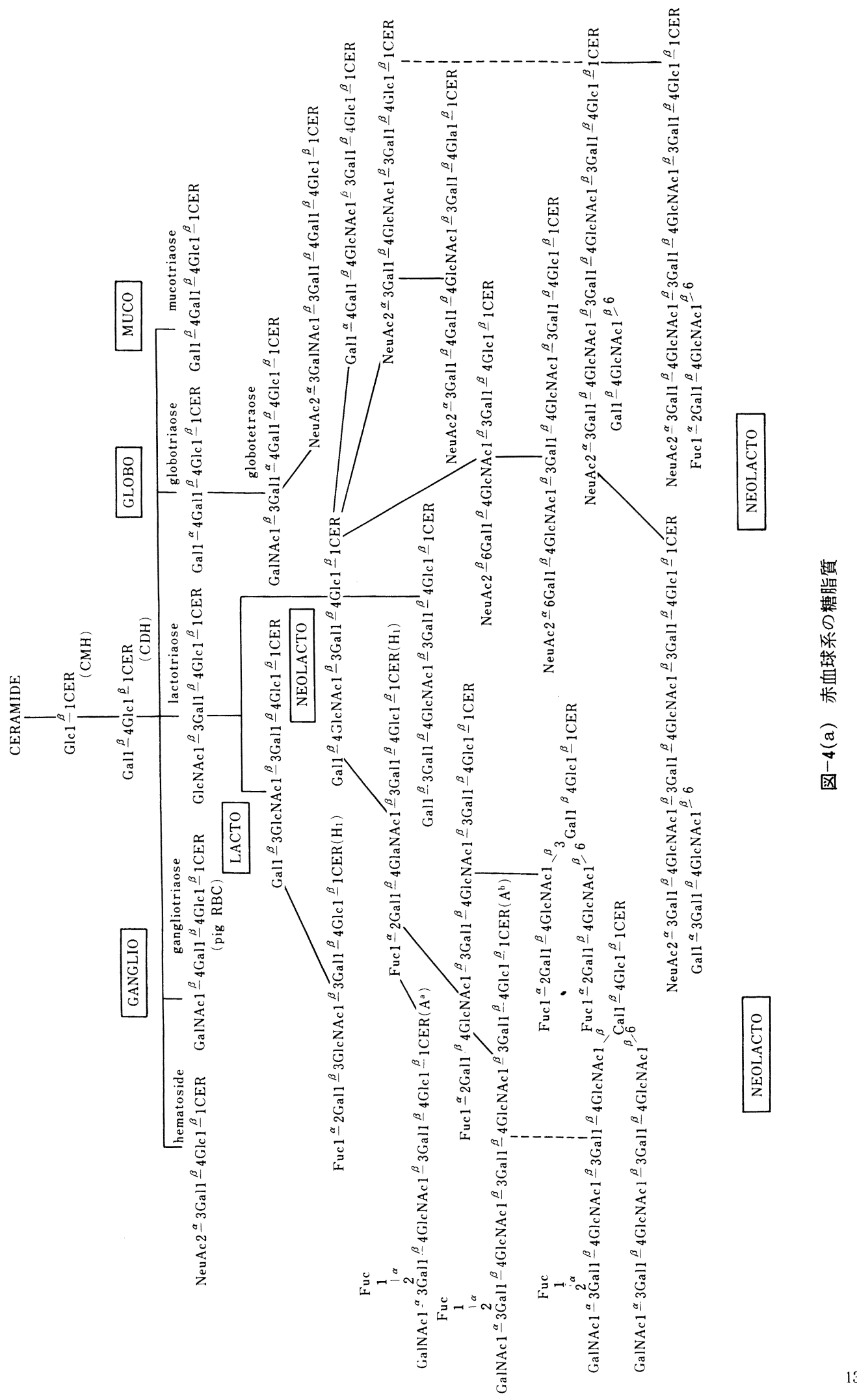




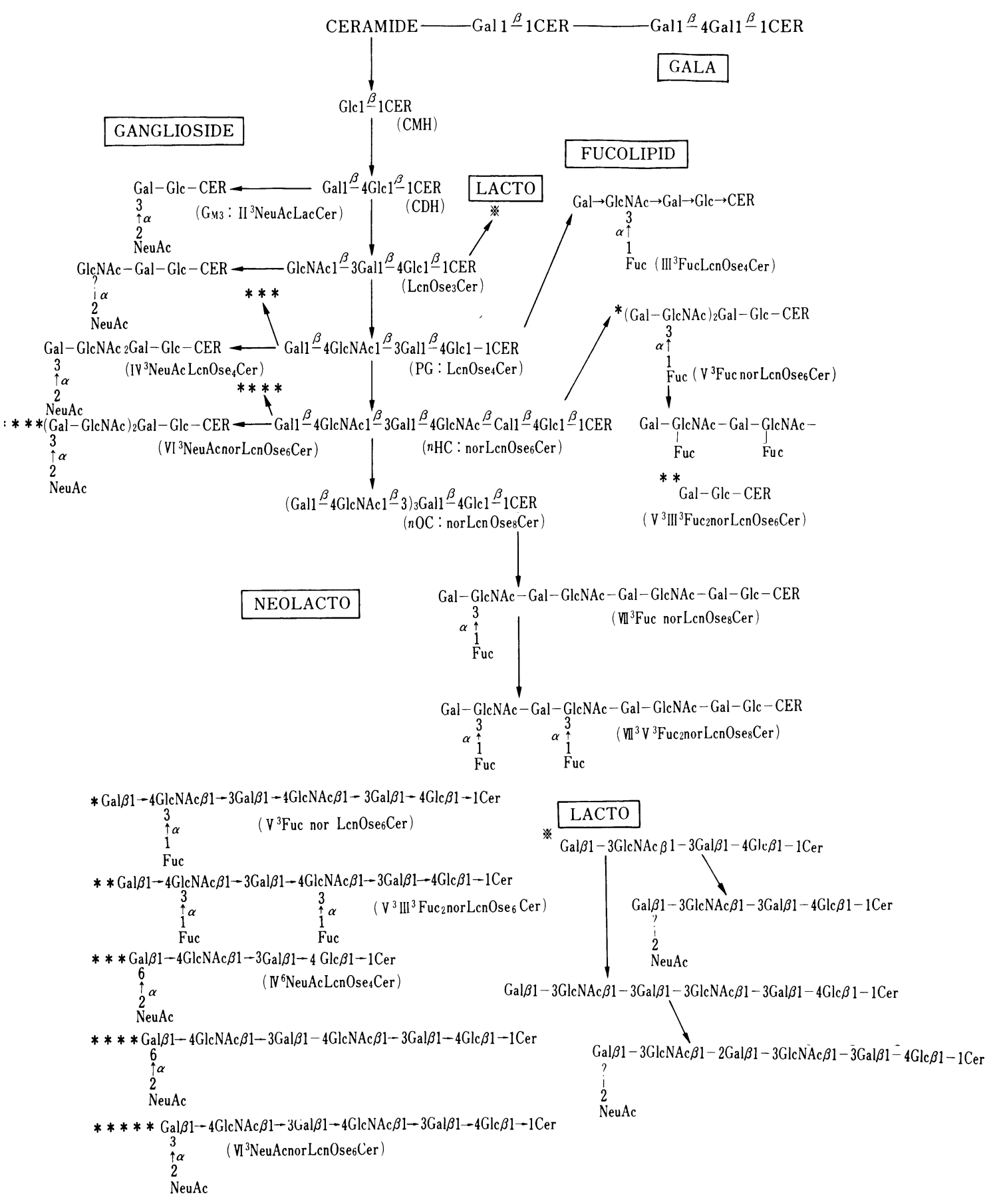

図-4(b) か粒球系の糖脂質

かりゅう球, リンパ球はおのおの固有の糖脂質パターン をもっている(図ー4)。赤血球ではグロボシド, $\mathrm{ABH}$ 血液型糖脂質, かりゅう球ではパラグロボシドのような ネオラクト系糖脂質, リンパ球ではセラミド・ジへキソ
シド CDH, セラミド・トリへキソシド CTH のような グロボ系糖脂質がおのおの主要成分となっている。特徵 的な糖脂質パターンはそれぞれの細胞系統の細胞社会学 上の機能的, 構造的相異を反映し、このパターンの特異 


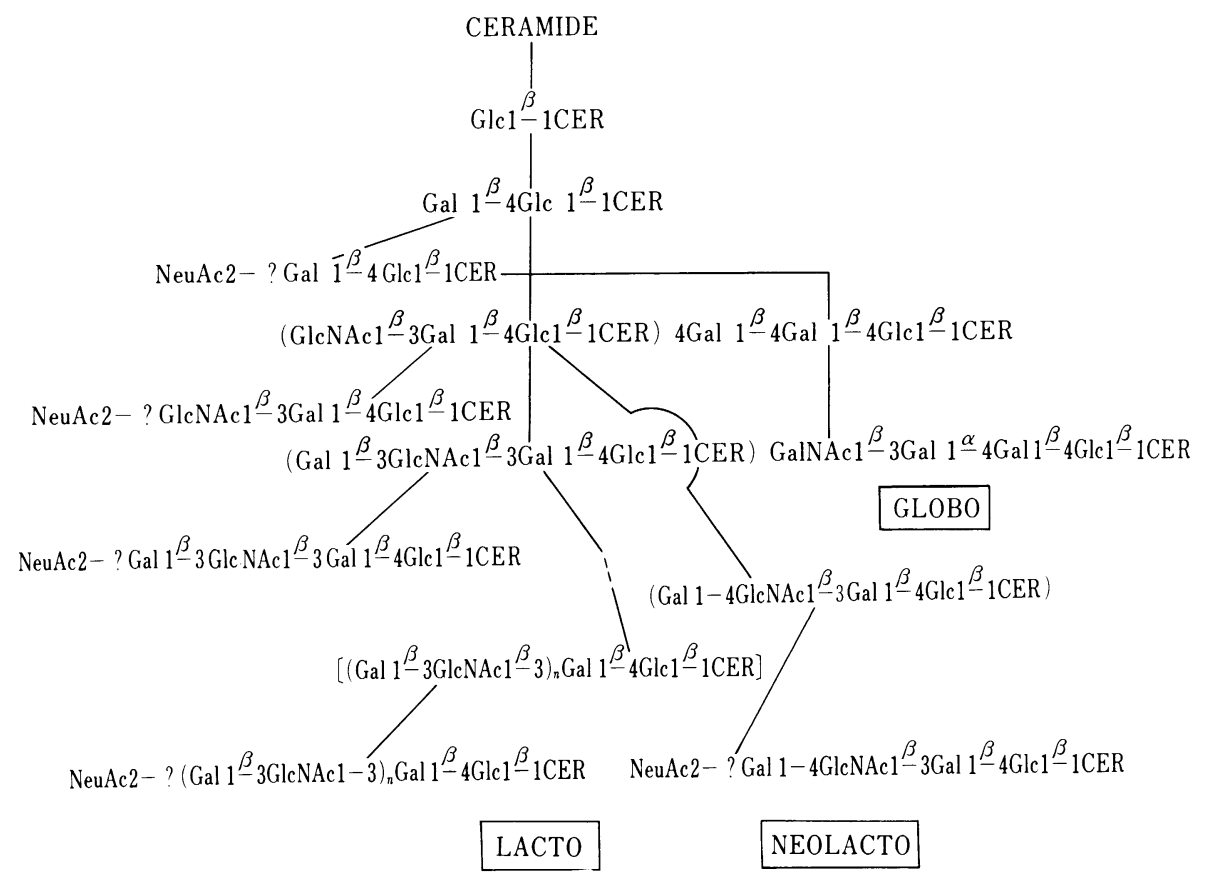

図-4(c) リンパ球系の糖脂質；（）内［〕 〕の構造は未証明

性により異なった細胞系統を相互識別して，ヒ卜白血病 鑑別診断等へ応用されている(7)。

しかし, 正常血球分化過程での糖脂質パターンについ ては赤血球分化段階の極く一部での変化 (i-I 抗原変換 など）を別にすればほとんど不明である。造血幹細胞及 び様々の分化段階の前駆細胞を同定し，化学的分析に耐 え得る充分量の均一細胞集団を収集することが技術的に 不可能だからである。すなわち, 現在の造血幹細胞測定 方法は骨髄やひ(脾)臓から単核細胞を分離し、これを (1) 放射線処理で造血能を完全に破壊した動物に注入. ひ臟に血液細胞コロニーを形成させる方法 $(C F U-S$ 測 定法 $)^{1)}$, あるいは (2) 様々の造血因子存在下に半固形 培地で培養, 種々の血球の組み合わせから成るコロニー を形成させる方法 (CFU-C, - E, - GEMM, BFU-E 等の測定法 $)^{11}$ によって，そのコロニー構成細胞を分析 して, 増殖・分化能の異なる様々な前駆細胞の存在を推 定する方法である。構成細胞の多様性から Totipotential, Multipotential, Oligo-/Uni-potential など, 幹 細胞の「Commitment」の程度を推測するのが現研究 段階である ${ }^{18)}$ 。細胞性がん原遗伝子 Protooncogene の研究から近い将来, 造血幹細胞及び各分化段階の前駆 細胞，おのおのを固有の分化段階で增殖させる遗伝子操 作が可能にな机ば，糖脂質を始めとする種々の微量膜構 成分の正常分化過程での「特徽的分子構築之機能」が明 らかになるものと期待される。

\section{$6 \cdot 1$ 血液型物質としての糖脂質}

$\mathrm{ABH}(\mathrm{O})$, Lewis 血液型物質の構造研究は 1950～1960 年代初めにかけて Morgan, Watkins, Kabat らによ り盛んに行われ, 型抗原特異性は糖鎖の構成単糖之結合 様式に依存すること, 特異的結合を形成する糖転移酵素 が第一次遗伝的支配を受けていること，等が判明した。 しかし当時の研究は主に分泌型の糖タンパクやオリゴ サッカリドについてなされたもので, 血液型抗原之称し ながら赤血球（膜）そのものに関する研究成果はほとん ぞ見当たらない。その後, 研究の流れはヒト赤血球膜上 の型抗原物質に向けられ，分離・精製後の収率は極めて 低いが、基本的には水不溶性の膜内物質であると考えら れるようになった。ここに抗原決定基の「キャリヤー」 としてスフィンゴ糖脂質が登場することになった。糖鎖 分解酵素処理, メチル化法, 質量分析法等を利用した糖 脂質の構造研究により $\mathrm{ABH}$, Lewis, Ii 式などの血液 型抗原の分子構造が明確になったばかりでなく，構造上 の多様性や免疫原性等も明らかになった。更に細胞表面 標識法, 膜内構成因子融解法, 膜糖タンパクのレクチン によるアフィニティ・クロマト分析法, エクソ及びエン ドグリコシダーゼの発見と応用等, 諸々の生体膜化学分 析法の目覚ましい発達により次々之様々な膜構成因子が 同定された。最近に至って $\mathrm{ABH}$, Lewis, P, Ii 式血液 型抗原決定基は糖脂質として赤血球膜上に表現される (表-1) のみでなく, 膜糖夕ンパク Band 3, Band 4.5 
表-1 赤血球における血液型・物質（抗原）としての糖脂質

ヒ卜赤血球

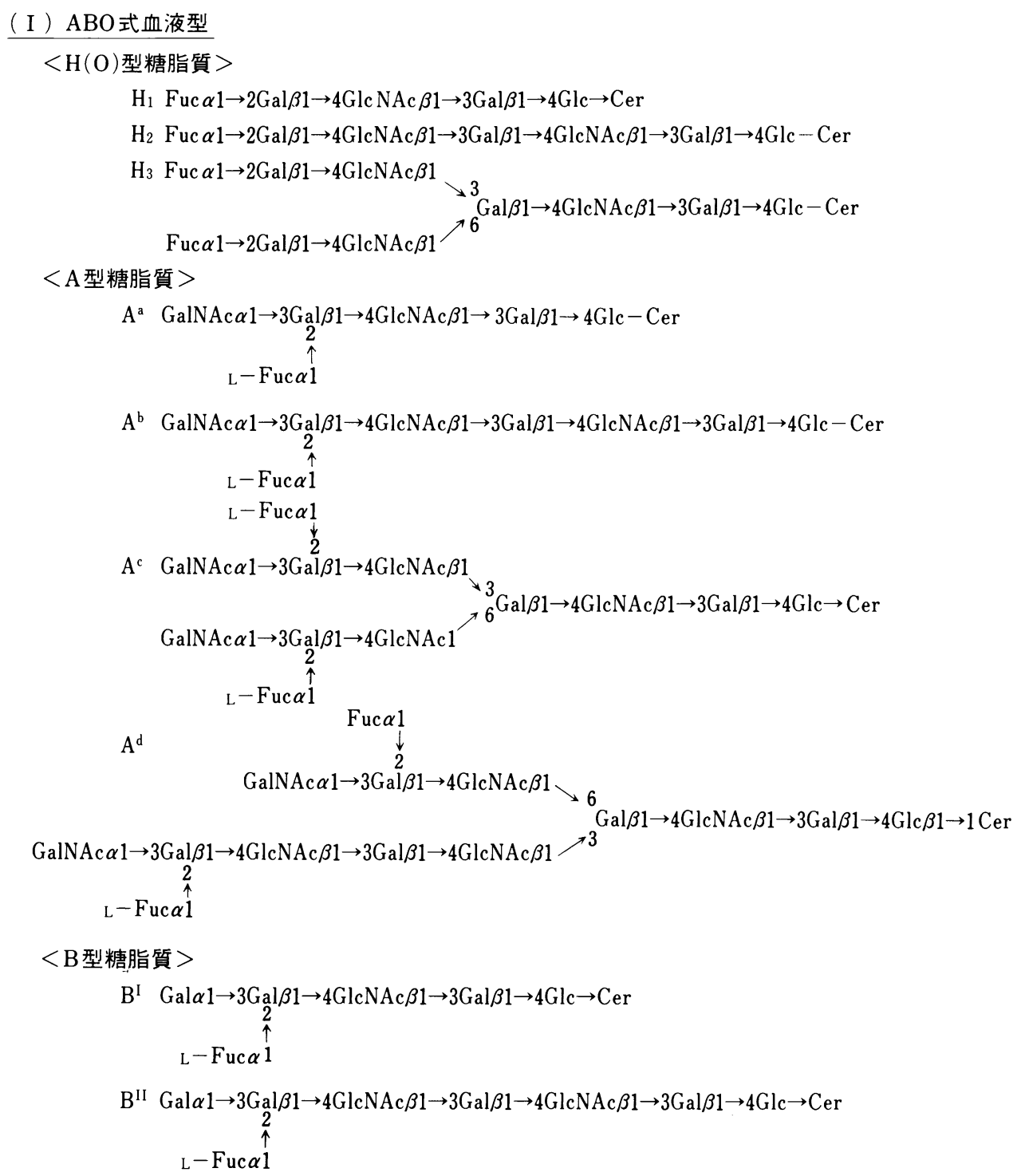

等にも存在する糖脂質・糖タンパク共通抗原であること が明白となった ${ }^{6)}$ 。異好性抗原のForssman 抗原, Hanganuzieu-Deicher 抗原なども糖脂質であること が実証されているが, 同時に糖タンパク糖鎖にもこれら の抗原決定群が見いだされることが多い。特に非還元末 端糖鎖が特異性の高い抗原性を示すことは末端糖鎖部分 による特異的血球凝集反応阻止や最近の単クローン抗体 作製実験なよ゙の結果から明白である。また糖脂質糖鎖は 糖タンパク糖鎖に比べ抗原性が高く, 一般にその糖鎖に 対する抗体ができやすい。これは分子中に占める糖鎖の 割合（三糖鎖構造で約 $50 \%$ )が高いこと，キャリヤー部
分に対する抗体産生の難易（キャリヤータンパク部分に 比べセラミド部分に対しては抗体ができにくいこと）等 上関連していると考えられる。過免疫することにより既 に自己が有する糖鎖構造に対する抗体が産生される現象 も, この事実と関連した糖脂質抗原の特徴の一つである。

\section{$6 \cdot 2$ 赤血球分化亡糖脂質パターン}

ほ乳類の成熟赤血球は脱核し内膜系も消失しているの で, 低張液処理, 遠心操作でほぼ均一な細胞膜の大量調 製が可能である。従って, 膜系微量構成分である糖脂質 についても構造解析を中心に詳細な研究がなされ, グロ ボ系, ネオラクト系糖脂質の存在が明らかにされた ${ }^{6)}$ 。 
表-1（つづき）

(II) Lewis 式血液型

$<$ Lewis 型糖脂質 $>$

$\mathrm{Le}^{\mathrm{a}} \mathrm{Gal} \beta 1 \rightarrow 3 \mathrm{GlcNAc} \beta 1 \rightarrow 3 \mathrm{Gal} \beta 1 \rightarrow 4 \mathrm{Glc} \rightarrow \mathrm{Cer}$ $\stackrel{4}{\uparrow}$

$\mathrm{L}-\mathrm{Fuc} \alpha 1$

$\mathrm{Le}^{\mathrm{b}} \mathrm{Gal} \beta 1 \rightarrow 3 \mathrm{GlcNAc} \beta 1 \rightarrow 3 \mathrm{Gal} \beta 1 \rightarrow 4 \mathrm{Glc} \rightarrow \mathrm{Cer}$

$\begin{array}{rr}2 & 4 \\ \mathrm{~L}-\mathrm{Fuc} \alpha \mathrm{l} & \mathrm{L}-\mathrm{Fuc} \alpha 1\end{array}$

(III) $\mathrm{P}$ 式血液型

$<\mathrm{P}$ 型糖脂質 $>$

$\mathrm{P}_{1} \quad \mathrm{Gal} \alpha 1 \rightarrow 4 \mathrm{Gal} \beta 1 \rightarrow 4 \mathrm{GlcNAc} \beta 1 \rightarrow 3 \mathrm{Gal} \beta 1 \rightarrow 4 \mathrm{Glc} \rightarrow \mathrm{Cer}$

$\mathrm{P} \quad \mathrm{GalNAc} \beta 1 \rightarrow 3 \mathrm{Gal} \alpha 1 \rightarrow 4 \mathrm{Gal} \beta 1 \rightarrow 4 \mathrm{Glc} \rightarrow \mathrm{Cer}$

$\mathrm{P}^{\mathrm{k}} \quad \mathrm{Gal} \alpha 1 \rightarrow 4 \mathrm{Gal} \beta 1 \rightarrow 4 \mathrm{Glc} \rightarrow \mathrm{Cer}$

(IV) Ii 式血液型

$<\mathrm{Ii}$ 型糖脂質 $>$

i $\mathrm{Gal} \beta 1 \rightarrow 4 \mathrm{GlcNAc} \beta 1 \rightarrow 3 \mathrm{Gal} \beta 1 \rightarrow 4 \mathrm{GlcNAc} \beta 1 \rightarrow 3 \mathrm{Gal} \beta 1 \rightarrow 4 \mathrm{Glc} \rightarrow \mathrm{Cer}$

I $\mathrm{Gal} \beta 1 \rightarrow 4 \mathrm{GlcNAc} \beta 1_{\searrow_{3}}$

$$
\mathrm{Gal} \beta 1 \rightarrow 4 \mathrm{GlcNAc} \beta 1^{\nearrow 6} 6^{\mathrm{Gal} \beta 1 \rightarrow 4 \mathrm{GlcNAc} \beta 1 \rightarrow 3 \mathrm{Gal} \beta 1 \rightarrow 4 \mathrm{Glc} \rightarrow \mathrm{Cer}}
$$

非ヒト赤血球

(V) 異好性抗原 (Heterophil Antigens)

Forssman 抗原

GalNAc $\alpha 1 \rightarrow 3 \mathrm{GalNAc} \beta 1 \rightarrow 3 \mathrm{Gal} \alpha 1 \rightarrow 4 \mathrm{Gal} \beta 1 \rightarrow 4 \mathrm{Glc} \rightarrow \mathrm{Cer}$

Hanganutziu - Deicher 抗原

Gangliosides containing $N$-glycolylneuraminic acid

NeuGc $\alpha 2 \rightarrow 3 \mathrm{Gal} \beta 1 \rightarrow 4 \mathrm{Glc}-\mathrm{Cer}$

$\mathrm{NeuGc} \alpha 2 \rightarrow 3 \mathrm{Gal} \beta 1 \rightarrow 4 \mathrm{GlcNAc} \beta 1 \rightarrow 3 \mathrm{Gal} \beta 1 \rightarrow 4 \mathrm{Glc} \rightarrow \mathrm{Cer}$

(VI) Stage-Specific Enbryonic Antigens (SSEA)

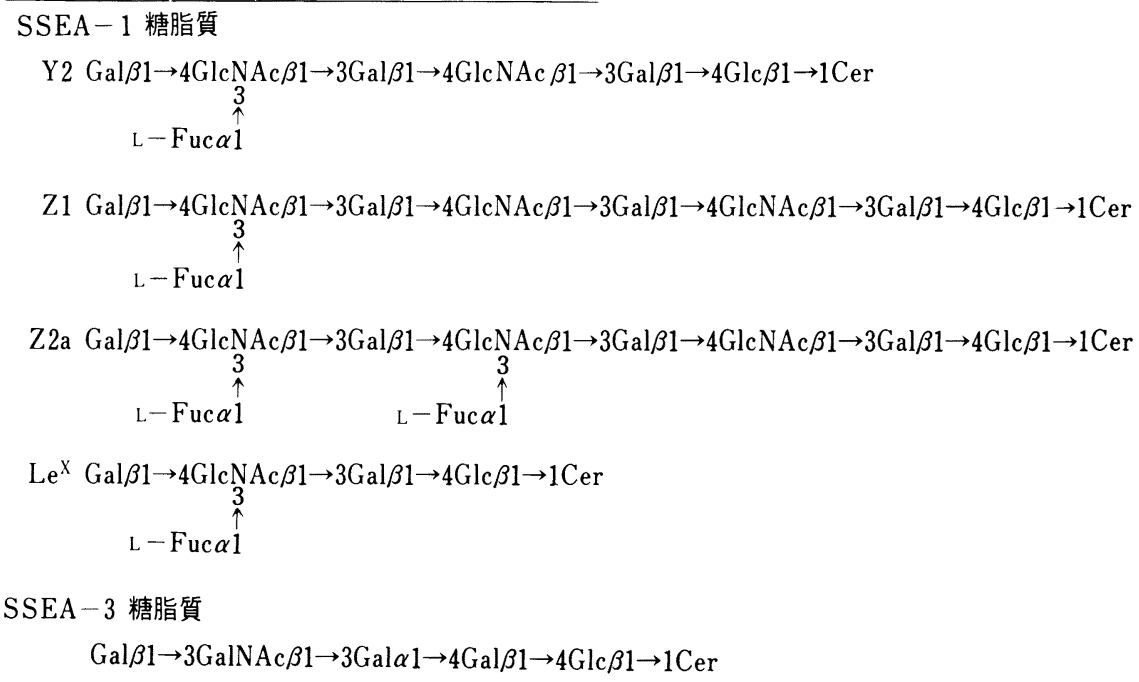


正常赤血球全分化過程における糖脂質パターンを化学的 レベルで解析することは現研究段階では不可能である が, 胎児, 新生児, 成人の各赤血球の表面抗原分析を行っ て, 分化の比較的終末に近い過程の糖脂質・糖夕ンパク 糖鎖の特徵的変化が明らかにされた：(1) 抗グロボシド 抗体による凝集性は胎児赤血球が新生児/成人赤血球に 比べ遙かに高い。こ机はグロボシド糖鎖の構造変化に由 来するのではなく，膜表面に露出した糖鎖が分化過程で 隠ぺいされる「masking」現象に基づく ${ }^{6)} ;(2) i \rightarrow I$ 抗 原変換はへモグロビン Fから Aへの合成切り換え時期に 一致する ${ }^{19)}$ ；(3) 胎坚赤血球では抗 i 抗体による凝集 性が高く, i 抗原は Lacto- $N$-nor-hexaosylceramide に代表される直鎖 $N$-アセチルラクトサミン繰り返し構 造の糖脂質で, 抗 I 抗体による凝集性の高い成人赤血球 には Lacto- $N$-isooctaosylceramide に代表される分 岐鎖構造の糖脂質が I 抗原として存在する ${ }^{20)} ;(4)$ 膜 糖夕ンパク Band 3, Band 4.5 も I, i 抗原決定基を有す

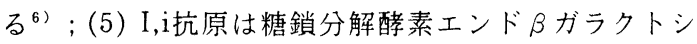
ダーゼで水解され抗原活性を失うが, 直鎖 $\mathrm{i}$ 抗原は分岐 鎖 I 抗原に比べより水解されやすく，両抗原を相対的に 区別できる ${ }^{6)} ;(6)$ i 抗原は出生後, 著減し, I 抗原は出 生後 1 年間に増加して成人赤血球のレベルに達する。I, i 抗原発現様式が自己免疫性溶血性貧血患者血清中に見 いだされる抗 I 及び抗 i 単クローン自然抗体を武器とし て詳細に解析されてきた経緯は大变興味深い。赤血球分 化に関連した分岐糖鎖形成現象は Branching enzyme 誘導によって生ずるが，これは $\mathrm{ABH}$ 血液型抗原につい ても観察される ${ }^{6)}$ 。H型抗原の分岐糖鎖構造(成人赤血 球に比へ胎児赤血球でより少なく, A, B型抗原について も 2 分岐鎖構造が胎児赤血球には欠けている ${ }^{6)}$ 。

\section{3 白血球系細胞の糖脂質パターン}

近年, 各血球成分の分離採取技術の進歩, 成分輸血之 いう臨床上の必要性から発達した連続遠心白血球分離装 置の出現によって, かなり均一な大量のかりゅう球, リ ンパ球, 血小板等の分離採取が可能となり, それらの糖 脂質, 糖タンパクについて次々と新しい化学構造が決定 されるようになった。

Macher と Klock は正常人末しょう(梢)血より化学 構造分析に耐え得る充分量 $\left(10^{10} \sim 10^{11}\right.$ 個) の， $95 \%$ 以上の純度をもつ好中性かりゅう球画分を分離( ${ }^{21)}$ ，

総脂質抽出, 中性之酸性脂質の分離, シリカゲル・カラ ムでの精製後, 高性能薄層 ${ }^{21}$ 又は高速液体 ${ }^{22}$ クロマト で糖脂質画分を単離した。これを質量分析，メチル化分 析, エンド/エクソ・グリコシダーゼ水解, 等を組み合 わせて構造解析し, 好中球糖脂質の特徴を明らかにし た：(1) 主要中性糖脂質は $\mathrm{CDH}$ とパラグロボシド，そ

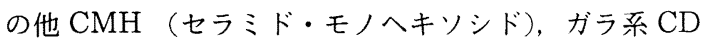
$\mathrm{H}$ (ジガラクトシルセラミド) が存在し, アミノ CTH
が $10 \%$ 程度存在する ${ }^{21}$ 。更に糖残基数 10 程度までの 直鎖型 $N$-アセチルラクトサミン骨格の中性糖脂質を有 し, 大部分は 1,2 個のフコースを結合して $\operatorname{Lex}[\mathrm{Gal} \beta 1$ $\rightarrow 4($ Fuc $\alpha 1 \rightarrow 3)$ GlcNAc $\rightarrow$ R] 構造をとる22)；(2) ガ ングリオシドは直鎖型 $N$-アセチルラクトサミン骨格の 非還元末端にシアル酸が $\alpha 2 \rightarrow 3 / 2 \rightarrow 6$ 結合した分子構 造をとる(ネオラクト系構造)。微量成分としてシアリ ル Lex 構造の分子種も存在する ${ }^{22)} ;(3)$ 各糖脂質は薄 層クロマト上 2 本のバンド対を成し, 一方が $\mathrm{C}_{16: 0}$ 他 方が $\mathrm{C}_{24: 1}$ の脂肪酸を持ち, 前者の分子種が主体を成 す。セラミド部分は長鎖塩基として $\mathrm{d}_{18: 1}$ のスフィン ゴシンを持つ。

リンパ球の糖脂質に関してはヒトへんとうせん（扁桃 腺） $\mathrm{T}, \mathrm{B}$ 両リン八球で 4 種類の中性糖脂質 $\mathrm{CMH}, \mathrm{CD}$ $\mathrm{H}, \mathrm{CTH}$, グロボシドが証明され233，更に末しょう血 リンパ球でも同定された ${ }^{24)}$ 。かりゅう球に比べ中性糖 脂質含量は, 細胞当たり 10〜15 倍, 細胞表面積当たり $3 \sim 4$ 倍多い。両細胞系とも $\mathrm{CDH}$ が主成分（全中性糖 脂質の 65 70\%)であるが，第 2 主成分（約 20\%）は好 中球でパラグロボシド, リンパ球では $\mathrm{CMH}$ である。 従ってリン八゚球では 3 糖鎖, 4 糖鎖分子種は $10 \%$ 以下で ある。分化過程でかりゅう球系統ではネオラクト系とガ ラ系, リンパ球系統ではグロボ系の中性糖脂質が主成分 を構成する。 T, B 両リンパ球共に 4 糖鎖分子としてグ ロボ系(グロボシド)とネオラクト采 (パラグロボシド) 両者をおのおの $1 \%, 3 \%$ 程度含有しているが, Bリンパ

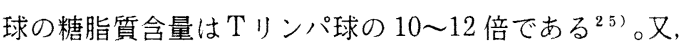
$\mathrm{T}, \mathrm{B}$ おのおのの細胞集団内での中性糖脂質発現の定性 的多様性が免疫学的に示されている。セラミド基はすべ ての中性糖脂質に共通で, 長鎖塩基は $\mathrm{d}_{18: 1}$ の 4-ス フィンゲニン, 脂肪酸は $\mathrm{C}_{16: 0}, \mathrm{C}_{24: 0}, \mathrm{C}_{24: 1}$ から成 る24)。ガングリオシド組成 ${ }^{26)}$ では $\mathrm{GM}_{3}$ が主成分であ るが, 微量のネオラクト系又はラクト系糖鎖構造の分子 種も存在し, 定性的にはかりゅう球に似るが定量的には 異なる。

マクロファージの糖脂質については：1) マクロ

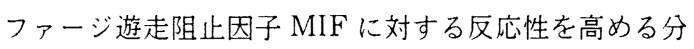
子種が存在する；2）この分子種においてはシアル酸之 共にフコース残基が重要である；3）この分子種そのも のが MIF 受容体である；4) モルモット腹こう(腔)マク ロファージから精製されたこの糖脂質がフコガングリオ シドであること 27) 等が判明し, 更にラット肉芽しゅ(腫) や腹こうマクロファージから精製，構造決定されたフコ リピド Gal $\alpha 1 \rightarrow 3($ Fuc $\alpha 1 \rightarrow 2)$ Gal $\beta 1 \rightarrow 3 \mathrm{Gal}$ NAc $\beta 1 \rightarrow 3$ Gal $\beta 1 \rightarrow 4$ Glc-Cer が MIF 阻害作用を 持つ MIF 受容体そのものであると予想された ${ }^{28)}$ 。結局 MIFはフコース残基を持つガングリオ系糖鎖と反応し， ラクト系糖鎖とは反応しないこと, フコース残基の結合 
様式を識別しないこと ${ }^{28)}$ ，又フコガングリオシドと類 似構造の「ガングリオタンパク」が MIF 受容体である 可能性もあること胡が明らかになった。

\section{$6 \cdot 4$ 血小板の糖脂質パターン}

七ト血小板の糖脂質研究は比較的少ない。トリプシン 処理血小板の総脂質からリン脂質 $(65 \%)$,中性脂質 $(25$ $\%)$ ，スフィンゴ糖脂質 $(10 \%)$ が分離され，中性糖脂 質 4 分子種, $\mathrm{CMH}$ (全中性糖脂質の $3 \%$ ), $\mathrm{CDH}$ (64

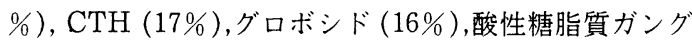
リオシド $\mathrm{GM}_{3}$ （全糖脂質の $15 \%$ ）が同定されてい $3^{29)}$.30)。主要構成脂肪酸は $\mathrm{C}_{20: 0}, \mathrm{C}_{22: 0}, \mathrm{C}_{24: 0}$, $\mathrm{C}_{24: 1}$, 長鎖塩基は主として 4-スフィンゲニン $(75 \sim 85$ $\%)$ ，微量成分として 4-スフィンガニン $(5 \sim 8 \%)$ が含ま 机る。一方, 遊離セラミド Ceramide が血小板に特徵 的に存在し ${ }^{30}$ ), その含量が予想以上に多量（全脂質の $1.3 \%$,全スフィンゴ糖脂質の $55 \%$ )であることが判明し $た^{29)}$ 。遊離セラミドの脂肪酸組成は中性糖脂質やガン グリオシド $\mathrm{GM}_{3}$ のそれとは明りょうに異なり，血小板 をタンパク分解醉素で処理するとガングリオシド $\mathrm{GM}_{3}$ 抽出量は增加するが, 遊離セラミド抽出量は不変である こと等から遊離セラミドは中性糖脂質やガングリオシド $\mathrm{GM}_{3}$ の単なる分解産物ではなく, 血小板を他の血球成 分から区別する特徴的なマーカーとなる29)。血小板総 脂質の $0.5 \%$ に相当するガングリオシドの $90 \%$ はガンク リオシド $\mathrm{GM}_{3}, 5 \%$ はシアロパラグロボシド又はガング リオシド $\mathrm{GM}_{1}, 2 \%$ はガングリオシド $\mathrm{GD}_{3}$ と構造不明 の 2 分子種に相当する ${ }^{31}$ 。

\section{7 白血病細胞分化亡糖脂質}

$7 \cdot 1$ 白血病幹細胞 $(\mathrm{L}-\mathrm{CFC})$ と白血病細胞分化

McCulloch ら ${ }^{32}$ 隐性骨髄性白血病について白 血病幹細胞 Leukemic Colony-Forming Cell ( $\mathrm{L}-$ $\mathrm{CFC}) 」$ の概念を提唱し, 分裂能力の高い $\mathrm{L}-\mathrm{CFC}$ から 他の大部分の白血病細胞は補給されているとした。従っ て L-CFC を根絶することが白血病治療には肝要であ る。一見均一な白血病細胞集団の中で $\mathrm{L}-\mathrm{CFC}$ は細胞 電気泳動法等で特定の亜集団として識別可能であり, 自 己複製と共に一部は分裂能を失って分化する。また，分 化段階や自己複製能等から L-CFCに多様性が認めら れ, そのコロニー構成細胞の形態には白血病病型による 特徵がある ${ }^{33)}$ 。この現象は「L-CFC が病型に関連す る細胞系統へ分化しやすい傾向を既に有している」こと を示す。一方，白血病細胞はしばしば「Lineage infi-

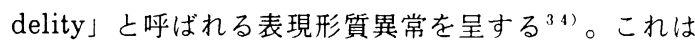
未分化細胞が基本的に有する多様な分化能あるいはしゅ よう（腫瘍）細胞における遗伝子発現の調節異常を反映 していると考えられる。

\section{$7 \cdot 2$ 白血病細胞の糖脂質パターン}

白血病は病態から慢性と急性に 2 大別され，前者は成 熟かりゅう球へ分化し得る慢性骨髄性白血病 CML 之, 成熟リンパ球様細胞に富む慢性リンパ球性白血病 CLL, 後者はリンパ球系初期分化が認められる急性リンパ球性 白血病 ALL, 骨髄・単球系への初期分化が証明できる急 性非リンパ性白血病 ANLLに分類される。すべての白 血病細胞に中性糖脂質 $\mathrm{CMH}$ と $\mathrm{CDH}$ が認められるが, 急性白血病細胞の $\mathrm{CDH}$ 量は正常白血球や慢性白血病細 胞に比べ $1 / 2 \sim 1 / 20$ に著減している。総脂質中の糖脂質 含量も急性白血病細胞で $0.5 \sim 4.9 \%$,正常白血球で $8.9 \sim$ $12.6 \%$, CML 細胞で $11.4 \sim 20.4 \%$ と，未分化細胞で減 少している。 ALL 細胞の中性糖脂質総量及び比較的長 糖鎖の CTH, グロボシド，パラグロボシド含量が ANLL 細胞に比べ非常に低い。ALL, ANLL 両白血病細 胞の 4 糖鎖中性糖脂質はグロボ系，ネオラクト系で，ガ ングリオ系分子種は見いだされない沾)。ALL 細胞で はグロボ系(グロボシド), ANLL 細胞ではネオラクト 系(パラグロボシド)が必ず表現されることは正常成熟リ ンパ球,かりゅう球, おのおのの主要 4 糖鎖中性糖脂質の 表現形に対応しており, 細胞系統に特徵的な糖鎖系列が しゅよう細胞でも既にその初期分化過程で表現されるも のと考えられる。一般に, 急性白血病細胞の中性糖脂質 は80 90\%が CMH, CDH であるが，急性前骨骾球性 白血病 APL 細胞のみは例外で CTH (40\%),グロボシ ド(19\%),パラグロボシド(6\%)の含量が目立って高く 4 糖鎖分子種の主成分がグロボ系という特徴が見られる。

B 細胞性 CLL 細胞の中性糖脂質は多様性を示すが, グロボ系分子種が主成分で，5１0\%がネオラクト系で ある。一方, CML 細胞の中性糖脂質パターンはネオラ クト系が主体で, 少量のガラ系が含まれ正常かりゅう球 のそれに類(似する ${ }^{36)}$ 。従って中性糖脂質パターンは骨 髄性 myeloid かリンパ性 lymphoid かの識別マーカー となる。細胞起源が問題となっていた慢性の Hairy 細 胞性白血病の構成細胞がグロボ系主体の中性糖脂質パ ターンを示すこと ${ }^{37)}$ からリンパ性起源であると考えら れている。

ALL 細胞ガングリオシド含量 $(2.6 \pm 0.9 \mu \mathrm{g}$ 脂質結 合型シアル酸 $/ 10^{8}$ 細胞) は ANLL 細胞のそれ (4.9土 $2.6 \mu \mathrm{g})$ の約 $1 / 2$ で, 正常リンパ球のガングリオシド含 量 $(2.5 \pm 0.5 \mu \mathrm{g})$ が正常かりゅう球のそれ $(3.8 \pm 1.5$ $\mu \mathrm{g})$ に比べ有意に低(現象に対応している ${ }^{38)}$ 。ガング リオシド含量では ANLL 細胞と正常かりゅう球之の間 に有意差はないが，そのパターンに明りょうな差異があ る。かりゅう球では長糖鎖ネオラクト系ガングリオシド 分子種が主成分であるが, ANLL 細胞では短糖鎖ガン グリオシド $\mathrm{GM}_{3}$ が主成分となり, 長糖鎖ネオラクト系

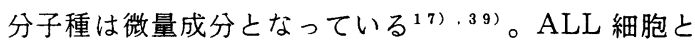
正常リンパ球のガングリオシド・パターンの間には明 
りょうな差異はなく，ガングリオシド GM が両者で主 成分である。

CML の成熟かりゅう球のガングリオシド含量は正 常成熟かりゅう球に比べ有意に低い39)。これはガング リオシド $\mathrm{GM}_{3}$ 含量の隇少によるもので, 他のガングリ オシド分子種含量に変化はない。また, CML 細胞では 分化・成熟度に並行してガングリオシド総量の増加, ネ オラクト系長糖鎖分子種の増加が見られる。このガング リオシド組成変化は HL-60 細胞のかりゅう球系分化 でも認められる ${ }^{39)}$ 。CML 細胞からガングリオシド 3 分子種, $\mathrm{GM}_{3}, \mathrm{SPG}$, シアリル・ノルヘキサオシルセラ ミド SnHC が同定された。SnHC には i 抗原活性が存 在する。正常かりゅう球に特異的なシアリルネオラクト ・トリアオシルセラミド $\mathrm{SnLTC}^{26)}$ も少量ではあるが CML 細胞に見いだされている40)。

近年著者らや ${ }^{411}$ Rosenfelder ら ${ }^{42)}$ によって, 多数 のヒト白血病・リンパしゅ細胞株の糖脂質, 特にガング リオシド・パターンが血球分化との関連で詳細に解析さ れ, 細胞系統・分化段階に特徴的なパターンが見いださ れた。すなわち同一細胞系統内や同一分化段階内の多様 性と, 異なる細胞系統間及び分化段階間における特異的 差異が明らかにされ, ガングリオシド・パターンから細 胞系統起源を推定することも可能である。

K 562 と HL-60 両株は 2 細胞系統以上への分化能を 有し, 分化の分岐機構研究に好都合である。前者は CML 急性転化症例から樹立された骨髄性未分化細胞 ${ }^{43)}$ であ るが, 赤血球系分化能が報告されて以来にわかに注目さ れるようになった。巨核球系分化現象も見いだされ，現 在では血液幹細胞的性格を持つと見なされている ${ }^{44)} 。$ 成熟赤血球と比較すると, 細胞当たり中性糖脂質含量は 約 7 倍, ガングリオシド含量は約 140 倍で, 糖脂質パター ンは全く異なる ${ }^{45)}$ 。赤血球の主要中性糖脂質グロボシ ドと第 3 成分 $\mathrm{CTH}$ の両グロボ系分子種は見いだされ ず, $\mathrm{CMH}$ が主要中性糖脂質, 第 2 成分 $\mathrm{CDH}$ は赤血球 と共通, ネオラクト系のパラグロボシドが微量成分とし て存在する。ガングリオシド組成ではガングリオ系がネ オラクト系より遙かに多く, 赤血球のそれの丁度逆関係 で, 赤血球にはほとど見いだされないガングリオシド $\mathrm{GD}_{1 \mathrm{a}}$ が主成分を成す。中性糖脂質/ガングリオシド相 対比が赤血球では $15: 1, \mathrm{~K} 562$ 細胞では $1: 1$ と大きく 異なる。糖脂質パターンは K 562 細胞赤血球系分化の 有用なマーカーとなり得る ${ }^{45)}$ 。

$\mathrm{HL}-60$ 細胞は Collins ら ${ }^{46)}$ が APL 細胞から樹立し た明りょうな分化能を持つ初めてのヒト白血病細胞株 で, ヒト白血病細胞分化研究の飛躍的進展の契機之なっ た ${ }^{47)}$ 。その後この細胞は好中球系分化のみでなく, 単 球マクロファージ系及び好酸球系へも分化し得る 2 方向 性 ${ }^{48)}$ (図-5) あるいは 3 方向性 ${ }^{49}$ 分化能を持っことが

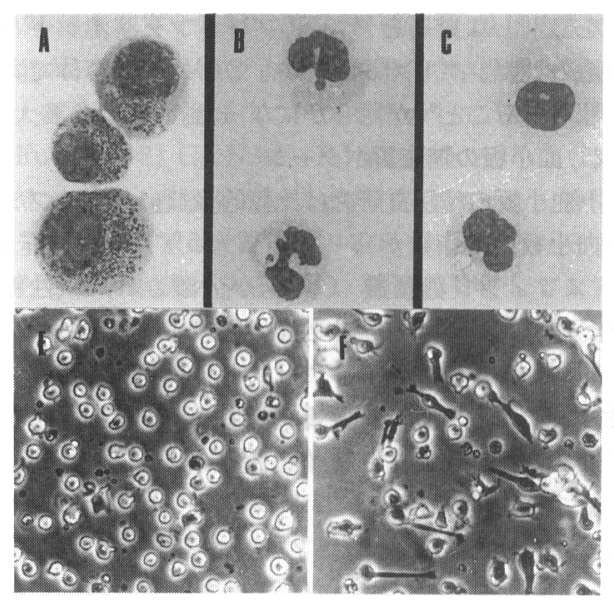

(A) 無処理対照 HL-60 細胞 (Cytospin smear, ラ イト・ギムザ染色)

(B) $1.3 \% \mathrm{DMSO}$ 処理 $6 \mathrm{~d}$ 後: かりゅう球系分化

(C) $4 \mathrm{nM} \mathrm{TPA}$ 処理 $3 \mathrm{~d}$ 後: 単球マクロファージ 系分化

（D）無処理対照 HL-60 細胞（位相差顕微鏡像）

(E) $4 \mathrm{nM} \mathrm{TPA}$ 処理 $24 \mathrm{~h}$ 後 : マクロファージ様接 着細胞の出現

図-5 HL-60 の細胞の 2 方向性分化 ${ }^{16)}$-47)

明らかとなり, 相異なる血球系統への分化方向決定機序 研究のための格好の実験モデルである。又これは正常造 血幹細胞の分化の振り分け之基本的に同じ現象が白血病 細胞でも生じることを示唆する。糖脂質に関しても HL -60 細胞の分化方向に依存した特異的組成变化が認めら れ, 特にガングリオシド・パターンの著変が注目され $3^{50)}$ 。しかし正常成熟かりゅう球の主要ガングリオシ ドの 1 分子種が成熟かりゅう球へ分化した HL-60 細胞 で微量成分のままである事実 ${ }^{39)}$ ５0) vitro 分化の不全性を意味している399，47)，50)。

$7 \cdot 3$ 白血病細胞の分化過程における糖脂質パターン の特徵的变化

HL-60 のかりゅう球采分化では長糖鎖ネオラクト系 分子種が増加しガングリオ系分子種が減少する, 一方, 単球マクロファージ分化では前者の分子種が減少, 後者 の分子種が増加する ${ }^{50)}$ ．51)。特にガングリオシド $\mathrm{GM}_{3}$ の增大は単球マクロファージ系分化に極めて特徴的で, 他の骨髄性細胞株 ML-1, KG-1, K 562 や単芽球性細 胞株 U 937 の分化でも共通している(図-6 $)^{52)}$ 。また, 生体内でのかりゅう球系分化モデルである CML 慢性期 細胞を分化段階で分画すると，分化度に従い「長糖鎖齐 オラクト系分子種増大, 短糖鎖ガングリオ系分子種 $\mathrm{GM}_{3}$ 減少」391.52) が観察される。すなわち造血系細胞 の糖脂質パターンは細胞の分化度だけでなく分化方向に 
(A) HL-60細胞の 2 方向性分化で活性化されると推定される 複合糖脂質合成経路

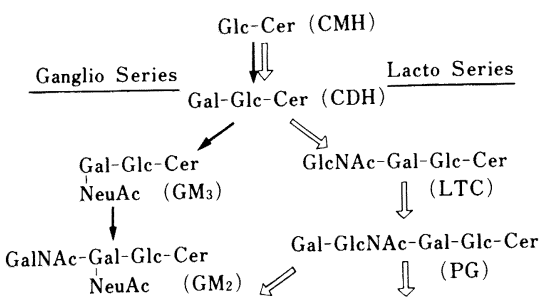

$\left(\mathrm{NeuAc}^{-}(\mathrm{Gal}-\mathrm{GlcNAc})_{n}-\mathrm{Gal}-\mathrm{Glc}-\mathrm{Cer}\right) \quad$ Gal-GlcNAc-Gal-Glc-Cer $(n=2 ; \mathrm{SnHc}) \quad$ NeuAc \&ु $(\mathrm{SPG})$

(LongerSugar-Chain Gangliosides)

(や）かりゅう球系分化で活性化が予想される代謝経路。

（ー）マクロファージ様細胞分化で活性化が予想される 代謝経路。

（B）種々の骨髄性白血病細胞株の単球マクロファージ系分化 において活性化される糖脂啠合成経路

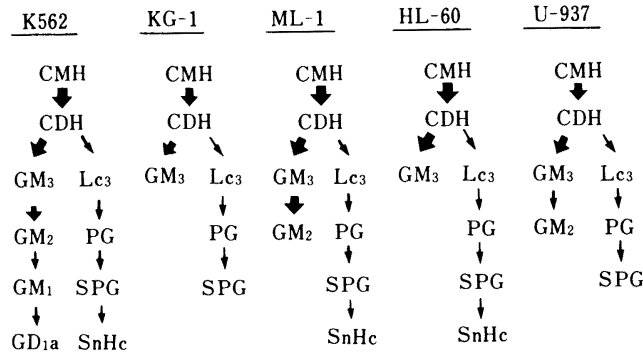

（注）矢印の太さは活性化の程度を表す。

図-6 分化の方向性に依存して活性化される糖脂質 合成経路 ${ }^{62)}$.64)

依存して特徴的に変化することが一般的で, 分化段階及 び細胞系統に特異性の高い分化マーカーになり得

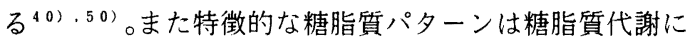
関与する酵素活性変化を反映する：例えば HL-60 細胞 の単球マクロファージ系分化でガングリオシド $\mathrm{GM}_{3}$ 合 成酵素(CMP-トランスフェラーゼシアル酸 : $\mathrm{CDH}$ シ アリルトランスフェラーゼ)活性が上昇, $\mathrm{GM}_{3}$ 水解酵素 (シアリダーゼ)活性が低下し, かりゅう球分化でシアリ ダーゼが活性化される現象 ${ }^{53}$ (3) (特徵的なガングリオシ ド・パターンの分析結果を裏付けている。すなわち, 単球 マクロファージ系分化ではガングリオ系ガングリオシド 合成経路が活性化され, かりゅう球系分化では長糖鎖ネ オラクト系ガングリオシド合成経路が活性化される(図 -6)。一般的に, 分化方向決定の際にスフィンゴ糖脂質 合成系は特定の分子種合成経路に变移するう1)のである。

\section{8 ガングリオシドの細胞分化誘導能}

\section{$8 \cdot 1$ ガングリオシド $\mathrm{GM}_{3}$ による単球・マクロファ ージ系分化誘導}

(A)

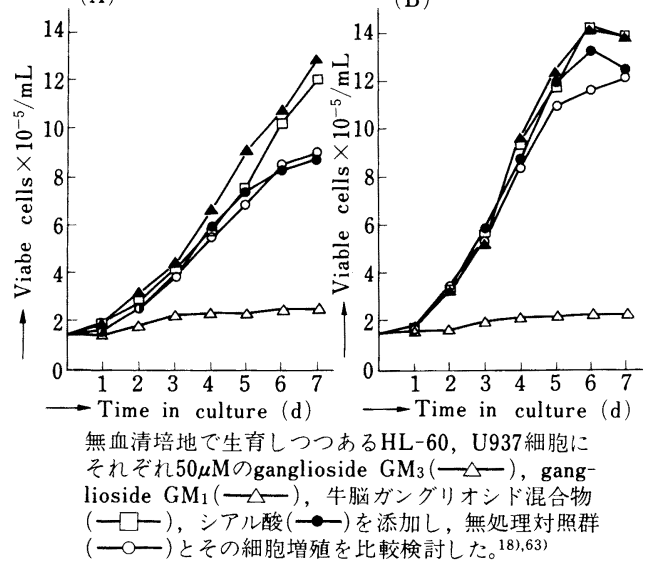

図-7 外因性ガングリオシド GM による HL-60(A) 及び U937(B)細胞の単球系分化誘導（細胞増殖 抑制)。

ヒト骨骨迶性白血病細胞の単球マクロファージ系分化誘 導50)，52．54)で特異的に増加するガングリオシド $\mathrm{GM}_{3}$ は種々の動物細胞にあまねく存在するシアロ糖脂質分子 で, 血球系では単核細胞 (単球, リンパ球等) や赤血球 の主要糖脂質成分を形成する。精製したガングリオシド $\mathrm{GM}_{3}$ を無血清培養系の $\mathrm{HL}-60$ 及び U 937 細胞に与え ると特異性の高い増殖抑制（図一7）上明りょうな単球マ クロファージ系分化が形態的に認められ ${ }^{15)}$.16)．55)

(図-8 B, F), 同時に単球マクロファージに特異的でか りゅう球との鑑別に用いられるフッ化ナトリウム感受性 の $\alpha$-ナフチルブチレートエステラーゼ活性の誘導が明 りょうに認められた（図-8 D, H)。更に成熟単球に特 異的な表面抗原が誘導され, 貪食能も増大する。 $\mathrm{GM}_{3}$ による増殖抑制, 分化誘導は新鮮白血病細胞の一次培養 においても共通して認められる ${ }^{56)}$ 。ガングリオ系ガング リオシド $\mathrm{GM}_{1}, \mathrm{GM}_{2}, \mathrm{GD}_{1 \mathrm{a}}, \mathrm{GD}_{1 \mathrm{~b}}, \mathrm{GT}_{1 \mathrm{~b}}$, 遊離シアル 酸では分化現象は全く起こらず, むしろ無血清培養系で は増殖が活性化される ${ }^{16)}$ ，51）（図一7）。

\section{2 シアロ糖脂質糖鎖構造と白血病細胞分化方向決} 定

著者らはかりゅう球系分化で特徴的に増加する $N-ア$ セチルラクトサミン直鎖構造の長糖鎖ネオラクト系がガ ングリオシドに着目し，この分子種を外来性に与えるこ とにより，HL-60 細胞がかりゅう球系成熟細胞に分化 する現象を最近発見した ${ }^{57)}$ 。使用した CML 慢性期か りゅう球のガングリオシド混合物は $96 \%$ がネオラクト 系分子種で構成され, 正常好中球に近似したガングリオ シド組成を示し ${ }^{39)}$ ，しかも HL-60 かりゅう系分化で 特徵的に増加するガングリオシド分子種がすべて含まれ ている。このガングリオシド標品によって, HL-60 細 胞は著明に増殖抑制され形態的に明りょうな成熟かりゅ 


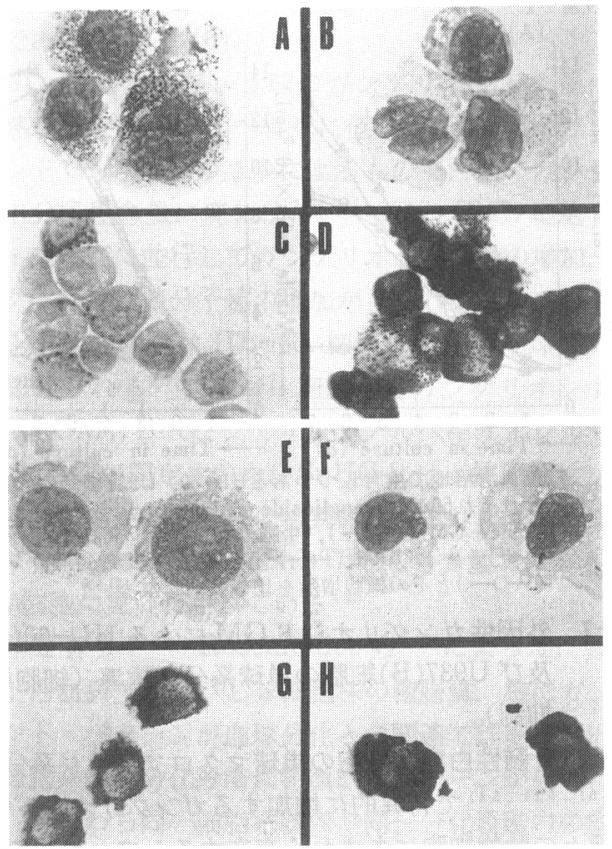

上図

カンングリオシド $\mathrm{GM}_{3}$ による $\mathrm{HL}-60$ 細胞の分化誘導に 観察される形態学的 $(\mathrm{A}, \mathrm{B})$ 及び細胞化学的 $(\mathrm{C}, \mathrm{D})$ 変 化。 $50 \mu \mathrm{M} \mathrm{GM}_{3}$ 添加, $6 \mathrm{~d}$ 培養し (B, D), 無処理対 照群 (A，C) と比較した。A，B は（ライト・ギームザ） 染色標本, C, D は非特異性エステラーゼ $(\alpha-N a p h t h y l$ butyrate esterase) 活性染色標本。

下図

ガングリオシド $\mathrm{GM}_{3}$ による U 937 細胞の分化誘導に観 察される形態学的 $(E, F)$ 及び細胞化学的 $(\mathrm{G}, \mathrm{H})$ 変化。 $50 \mu \mathrm{M} \mathrm{GM}_{3}$ 添加, $6 \mathrm{~d}$ 培養し $(\mathrm{F}, \mathrm{H})$ ), 無処理対照群 ( $\mathrm{E}$, G) と比較した。E, F は（ライト・ギームザ）染色標本， G, H は非特異性エステラーゼ ( $\alpha$-Naphthyl butyrate esterase) 活性染色標本。

図-8ガングリオシド $\mathrm{GM}_{3}$ による HL-60 及び U 937 細胞の分化誘導 ${ }^{15}$ ，16)，51)。

う球へ分化する ${ }^{57)}$ 。すなわち骨髄性白血病細胞の分化 方向決定におけるガングリオシド糖鎖構造特異性の第一 義的意義が強く示唆さ机る(図 -9 )。

$8 \cdot 3$ 神経細胞及びじん細胞に対するガングリオシド の分化誘導能

ガングリオシドの細胞分化誘導能に関しては永井・辻 らの極めて重要な発見がある58).59)。Tay-Sachs 病 の動物モデルにおけるガングリオシドの蓄積した巨大な 神経細胞の存在とその細胞から出た極好多くのかつ巨 大な神経突起の発見に端を発したガングリオシドと神経 機能の関連は彼らの「超微量のガングリオシド GQ 1 b
によるヒト神経芽細胞（株）における神経突起の数と長 さの増大」という発見によって新しい展開を見せている。 またじん臟上皮細胞由来の細胞株 MDCK のドーム形成 がガングリオシド $\mathrm{GM}_{3}$ や $\mathrm{GD}_{3}$ によって増大する現 象 ${ }^{60)}$ もガングリオシドの分化誘導能の一つの発現と考 元られる。

\section{9 分化謤導機構及び分化誘導能を有する 糖脂質類縁体の将来性}

ガングリオシド $\mathrm{GM}_{3}$, 長糖鎖ネオラクト系ガングリ オシド，それぞれによって引き起こされる HL-60 細胞 のタンパク質リン酸化反応は化学誘導剂での単球マクロ ファージ系, かりゅう球系おのおのの分化で観察される

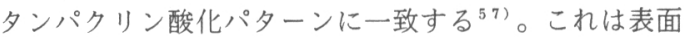
膜ガングリオシドの特異的分子種構築変化により引き起 こされるシグナル伝達の細胞系統特異性を反映している 上考えら机る。また特定シアロ糖脂質分子種の分化誘導 能は白血病細胞を分化に必須な糖脂質分子種構築の発現 不全と考元，その不全状態を外来性に補填すること（糖 脂質による細胞膜修飾）により，特定系統の成熟細胞一 分化誘導し得るという新しい病態生理（図一9）を意味し ているとも考えられる。これは新鮮白血病細胞 ${ }^{56)}$ や細 胞株 K $562^{611}$ を使った実駼結果からも支持される。最 も注目すべきことは分化進行中に量的に増大するシアロ 糖脂質分子種それ自体が分化誘導能を有しているという 発見であり，この事実は前述したガングリオシド $\mathrm{GQ}_{1 \mathrm{~b}}$ の神経細胞分化誘導能についての辻・永井らの発 見 ${ }^{58)}$ ．59）之共に，いまだその生理活性について不明な 点の多い膜分子群「糖脂質」が極めて重要かつ生理的意 義の深い活性を担っていることを実証したもの之考えら 机る。

分化誘導機序上して一般に，(1) 細胞膜リン脂質代謝 変化, 特にメチル化抑制によるリン脂質分子構築変化, (2) 細胞内骨格・収縮タンパク質の变化（リン酸化上脱

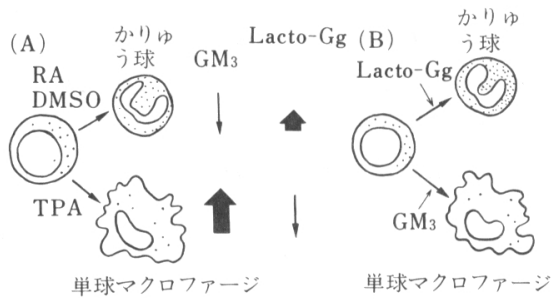

RA：レチノイン酸, DMSO : ジメチルスルホキシド, TPA : フォルボールエステル, Lact-Gg : ネオラク ト系ガングリオシド, $\mathrm{GM}_{3}$ : ガングリオシド $\mathrm{GM}_{3}$

図-9 HL-60の 2 方向性分化現象でのガングリオシド 分子種構成の特徵的変化 (A) と外因性ガングリ オシドによる分化誘導 $(B)^{57}$ 
リン酸化), (3) 遗伝子情報発現機序の修飾（核酸合成 及びタンパク合成の調節) 等が提唱され, また様々な分 化調節機序が唱えられている。強力な分化誘導剤 TPA のリセプターは $\mathrm{Ca}^{2+}$ で活性化されるタンパクリン酸化 酵素 $\mathrm{C}(\mathrm{C}$-キナーゼ) で, この活性発現にはリン脂質 ホスファチジルセリンとジアシルグリセリンが重要な役 割を担い, 細胞形態維持, 接着性等に関与する細胞骨格

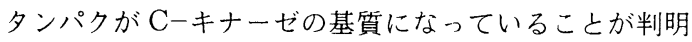
し, 白血病細胞分化の際の形態変化が機能変化亡共に分 子レベル解明されつつある。また, 細胞の生存に基本的 な役割を持ついくつかの細胞性がん原遺伝子 Protooncogene の発現抑制が分化誘導機序に密接に関連してい る事実 ${ }^{62)}$ が報告されてから数年を経る。しかしその本 体解明は今後に残された大きな課題である。

シアロ糖脂質ガングリオシドは生理的物質ながら, 既 知の生物学的反応修飾物質 BRM とは全く異なり, 表 面膜活性を持ち特異な作用機序が想定される新しい分化 誘導物質である。著者らは, 最近, 分化誘導剤レチノイ ン酸 RA に耐性となった HL-60 变異株 (RA r - HL -60) ではネオラクト系長糖鎖ガングリオシド分子種が 親株に比べ著减していること，一方，このネオラクト系 ガングリオシドを外来性に耐性株に与えると分化が誘導 されることを発見した ${ }^{631}$ 。この現象は薬剤耐性白血病 をガングリオシドで治療し得る可能性を示唆し, シアロ 糖脂質及びその有機合成類似体の臨床薬剤としての開発 の将来性を約束するものと考えたい。

最近, 小川ら ${ }^{64)} に よ り$ 完全有機合成されたガングリ オシド $\mathrm{GM}_{3}$ に天然体と同様な分化誘導活性が見いださ れた ${ }^{65)}$ 。現在では,より高級なガングリオシド分子（例 えば SPG）の有機合成も可能となっており，また有機 合成された多種類の脂質性シアロ糖化合物を検索した之 ころ, 一種のネオグリコリピド（自然界に存在しない糖 脂質), シアロコレステロール, に強力な分化誘導活性が 見いだされた ${ }^{66)}$ 。生体毒性も低いことから有効な抗白 血病剤になり得ると期待される。

\section{おわりに}

すべての動物細胞に存在する糖脂質は生命の基本的機 能を担い, またその欠損が悪性転換のような細胞社会学 的異常行動に結びつく糖脂質はなんらかの明確な生理的 機能を持っているもの之考えられる。糖脂質を介する生 体膜現象の多くは膜夕ンパク系上の相互作用の上にあ り, 真の糖脂質の生理機能解明には, より広い観点から の解析が必要である。糖脂質は直接に表面膜脂質二重層 に侵入，局在することができるので，糖タンパクに比べ 「情報伝達」には，より適しているが，一方，外界のリ ガンドと反応するには糖タンパク糖鎖の方が，より優れ ているとも考えられる。従って糖タンパクから糖脂質へ
の 2 段階相互作用のような生理機構が考えやすいように も思われる。生物・医学的観点からこの一連の研究を更 に推し進め, 糖脂質分子群の生理機能の本態を究明し,

医学上の応用性を追究することが期待される。

\section{謝 辞}

本総説中の当造血発生講座の研究内容に関しては中心 的役割を演じた講座助手 野尻久雄博士を始めとする当 教室のメンバー, 並びに本研究を支援して下さった恩師, 東大医学部教授 永井克孝, 高久史磨両先生に紙面を借 りて深謝致します。（昭和 63 年 7 月 28 日受理）

\section{文献}

1) M. Ogawa, P.N. Pharr, T. Suda, "Hemopoietic Stem Cell Physiology”, Alan R. Liss, New York (1985), p. 11

2) J.J. Tretin, "Regulation of Hematopoiesis", Appleton Century Crofts, New York (1970), p.161

3) N.A. Nicola, G.R. Johnson, Blood, 60, 1019 (1982)

4) S. Hakomori, "Sphingolipid Biochemistry", Plenum Press, New York (1983), p. 1

5) G. Rosenfelder, R.V.W. Van Eijk, P.F. Muhlradt, Eur. J. Biochem., 97, 229 (1979)

6) S. Hakomori, "Sphingolipid Biochemistry", Plenum Press, New York (1983), p. 327

7) J.L. Simmons, P.H. Fishman, E. Freese, R.O Brady, J. Cell Biol., 66, 414 (1975)

8) E. Huberman, C. Heckman, R. Langenbach, Cancer Res., 39, 2618 (1979)

9) L.M. Patt, K. Itaya, S. Hakomori, Nature, 273 379 (1978)

10) W.D. Merritt, D.J. Morre, T.W. Keenan, J. Natl. Cancer Inst., 60, 1329 (1978)

11) T. Taki, Y. Hirabayashi, Y. Ishiwata, M. Matsumoto, K. Kojima, Biochim. Biophys. Acta, 572, 113(1979)

12) G. Yogeeswaran, B.S. Stein, J. Natl. Cancer Inst., 65, 967 (1980)

13) T.W. Keenan, E. Schmid, W.W. Franke, H. Wiegandt, Exp. Cell Res., 92, 259 (1975)

14) E.G. Bremer, S. Hakomori, Biochem. Biophys. Res. Commun., 106, 711 (1982)

15) M. Saito, Y. Terui, H. Nojiri, Biochem. Biophys. Res. Commun., 132, 223 (1985)

16) H. Nojiri, F. Takaku, Y. Terui, Y. Miura, M. Saito, Proc. Natl. Acad. Sci. USA, 83, 782 (1986)

17) Y. Terui, H. Nojiri, M. Ohta, Y. Miura, M. Saito, Cancer Res., (1988)（投稿中）“A clinical application of ganglioside patterns of leukemic cells in differential diagnosis of human acute myelogenous and lymphoid leukemias, and of myeloid and lymphoid blastic crises of human chronic myelogenous leukemia"

18）斎藤政樹, 代謝, 23, 81 (1986)

19) A. Maniatis, T. Papayannopoulou, J.F. Bertles, Blood, 54, 159 (1979)

20) K. Watanabe, S. Hakomori, R.A. Childs, T. Feizi, J. Biol. Chem., 254, 3221 (1979) 
21) B.A. Macher, J.C. Klock, J. Biol. Chem., 255, 2092 (1980)

22) M.N. Fukuda, A. Dell, J.E. Oates, P. Wu, J.C. Klock, M. Fukuda, J. Biol. Chem., 260, 1067(1985)

23) K.E. Stein, D.M. Marcus, Biochemistry, 16, 5285 (1977)

24) W.M.F. Lee, J.C. Klock, B.A. Macher, Biochemistry, 20, 3810 (1981)

25) G.A. Schwarting, Biochem. J., 189, 407 (1980)

26) B.A. Macher, J.C. Klock, M.N. Fukuda, M. Fukuda, J. Biol. Chem., 256, 1968 (1981)

27) D.Y. Liu, K.D. Petschek, H.G. Remold, J.R. David, J. Biol. Chem., 257, 159 (1982)

28) T. Miura, S. Hanada, T. Yamakawa, J. Biochem., 86, 773 (1979)

29) R.V.P. Tao, C.C. Sweeley, G.A. Jamieson, J. Lipid Res., 14, 16 (1973)

30) W. Krivit, S. Hammarstrom, J. Lipid Res., 13, 525 (1972)

31) A.J. Marcus, H.L. Ullman, L.B. Safier, J. Clin. Invest., 51, 2602 (1972)

32) E.A. McCulloch, A.F. Howatson, R.N. Buick, M.D. Mindan, C.A. Izaguirre, Blood Cells, 5, 261 (1979)

33) K. Ozawa, Y. Miura, T. Suda, K. Motoyoshi, F. Takaku, Cancer Res., 43, 2334 (1983)

34) E.A. McCulloch, Blood, 62, 1 (1983)

35) W.M.F. Lee, M.A. Westrick, J.C. Klock, B.A. Macher, Biochim. Biophys. Acta, 711, 166 (1982)

36) J.C. Klock, J.L. D'Angona, B.A. Macher, J. Lipid Res. , 22, 1079 (1981)

37) W.M.F. Lee, J.C. Klock, B.A. Macher, Biochemistry, 20, 6505 (1981)

38) A. Tsuboyama, F. Takaku, S. Sakamoto, Y. Kano, T. Ariga, T. Miyatake, Br. J. Cancer, 42, 908 (1980)

39) I. Nojiri, F. Takaku, M. Ohta, Y. Miura, M. Saito, Cancer Res., 45, 6100 (1985)

10) M.A. Westrick, W.M.F. Lee, B.A. Macher, Cancer Res., 43, 5890 (1983)

11) M. Saito, H. Nojiri, F. Takaku, J. Minowada, "New Vistas in Glycolipid Research", Plenum Press, New York (1982), p. 369

42) G. Rosenfelder, A. Ziegler, P. Wernet, D.G. Braun, J. Natl. Cancer Inst., 68, 203 (1982)

43) B.B. Lozzio, C.B. Lozzio, Leukemia Res., 3, 363 (1979)

44) B.B. Lozzio, C.B. Lozzio, E.G. Bamberger, A.S. Feliu, Proc. Soc. Exp. Biol. Med., 166, 546 (1981)

45) A. Suzuki, R.A. Karol, S.K. Kundu, D.M. Marcus, Int. J. Cancer, 28, 271 (1981)

46) S.J. Collins, R.C. Gallo, R.E. Gallagher, Nature, 270, 347 (1977)

47）斎藤政樹。“癌細胞の分化誘導と制癌”, ソフトサイエン 又社, 東宗 (1985) p. 123

48) J.A. Fontana, D.A. Colbert, A.B. Deisseroth, Proc. Natl. Acad. Sci. USA, 78, 3863 (1981)

49) S.A. Fischkoff, A. Pollak, G.J. Gleich, J.R. Testa, S. Misawa, T.J. Reber, J. Exp. Med., 160, 179
(1984)

50) H. Nojiri, F. Takaku, T. Tetsuka, K. Motoyoshi, Y. Miura, M. Saito, Blood, 64, 534 (1984)

51) M. Saito, H. Nojiri, Y. Miura, "Experimental Hematology Today-1985”, Springer-Verlag, New York (1986) p. 64

52) H. Nojiri, F. Takaku, Y. Miura, M. Saito, J. Natl. Cancer Inst., (1988)（投稿中）“Common and consistent changes of sialoglycosphingolipid patterns during macrophage-like cell differentiation of various human myeloid leukemia cell lines induced with tumor promoters, 12-O-tetradecanoyl phorbol 13-acetate (TPA) and teleocidin B"

53) H. Nojiri, F. Takaku, T. Tetsuka, M. Saito, Biochem. Biophys. Res. Commun., 104, 1239 (1982)

54) T. Momoi, J. Yokota, J. Natl. Cancer Inst., 70, 229 (1983)

55) H. Senoo, T. Momoi, Biosci. Rep., 5, 517 (1985)

56) M. Ohta, H. Nojiri, Y. Miura, M. Saito, Cancer Res., (1988)（投稿中) “Differentiation of leukemic cells in primary cultures from human acute myelocytic leukemia induced with ganglioside $\mathrm{GM}_{3}$ ”

57) H. Nojiri, S. Kitagawa, M. Nakamura, K. Kirito, Y. Enomoto, M. Saito, J. Biol. Chem., 263, 7443 (1988)

58) S. Tsuji, M. Arita, Y. Nagai, J. Biochem., 94, 303 (1983)

59) S. Tsuji, J. Nakajima, T. Sasaki, Y. Nagai, J. Biochem., 97, 969 (1985)

$60)$ N. Rodrig, T. Osanai, M. Iwamori, Y. Nagai, FEBS Lett., 221, 315 (1987)

61) K. Kirito, H. Nojiri, M. Saito, J. Natl. Cancer Inst., (1988)（投稿中）“Multi-lineage differentiation of human myelogenous leukemia cell line K 562 cclls induced with ganglioside $\mathrm{GM}_{3}$ "

62) J.M. Bishop, Ann. Rev. Biochem., 52, 301 (1983)

63) S. Kitagawa, H. Nojiri, M. Nakamura, R.E. Gallagher, M. Saito, J. Biol. Chem., (1988)（投稿中） “Human promyelocytic leukemia cell line $\mathrm{HL}-60$ cells resistant to differentiation-induction by retinoic acid: Hyposialylation of glycosphingolipids and granulocytic differentiation by neolacto -series gangliosides"

64) M. Sugimoto, T. Ogawa, Glycoconjugate J., 2, 5 (1985)

65) M. Saito, H. Nojiri, Y. Nagai, T. Ogawa, Japan. J. Cancer Res., (1988)(投稿中) “Differentiation of human promyelocytic leukemia cell line HL-60 cells along the monocyte-macrophage lineage when induced with a synthetic glycosphingolipid structurally corresponded to natural ganglioside $\mathrm{GM}_{3}$ ”

66) M. Saito, II. Nojiri, H. Ogino, M. Akashi, M. Ito, II. Ogura, Y. Nagai, S. Kitagawa. J. Biol. Chem., (1988)（投稍中1) “ Granulocytic differentiation of human promy clocytic leukemia cell line HL-60 cells induced by a neoglycolipid, $\alpha$-sialocholesterol, but not by a stereoisomer, $\beta$-sialocholesterol" 